\title{
Crustal Velocity Structures Imaged from Four-Component OBS Data Across the Southern Gagua Ridge in the Western Philippine Sea
}

\author{
Jia-Ming Deng ${ }^{1}$, Tan-Kin Wang ${ }^{1, *}$, Ting-Ren Chen ${ }^{1}$, Chao-Shing Lee ${ }^{1}$, and Char-Shine Liu ${ }^{2}$ \\ ${ }^{1}$ Institute of Applied Geosciences, National Taiwan Ocean University, Keelung, Taiwan, R.O.C. \\ ${ }^{2}$ Institute of Oceanography, National Taiwan University, Taipei, Taiwan, R.O.C.
}

Received 25 March 2014, revised 27 July 2014, accepted 28 August 2014

\begin{abstract}
Crustal structures near a linear oceanic ridge, the Gagua Ridge, between the West Philippine Basin and the Huatung Basin in the western Philippine Sea were imaged based on head-wave, refracted and reflected P-wave arrivals recorded from 24 oceanbottom seismometers (OBS). Velocity anomaly zones, one below the Gagua Ridge summit and the others beneath two toes of the Gagua Ridge, imaged by large lateral variations in P-wave velocity of $5.5-6.4 \mathrm{~km} \mathrm{~s}^{-1}$ and low velocity of $4-5 \mathrm{~km} \mathrm{~s}^{-1}$ in the upper crust may have been generated when the Gagua Ridge was formed. East of the ridge, velocity anomaly zones, constrained by large lateral variations in P-wave velocity $\left(4.8-6.4 \mathrm{~km} \mathrm{~s}^{-1}\right)$, relatively low velocity $\left(4-5 \mathrm{~km} \mathrm{~s}^{-1}\right)$ and laterally high anomaly of Poisson's ratio (0.02-0.04) in the upper crust and abrupt crustal thickening $(6-8.5 \mathrm{~km})$ northward were obtained. West of the ridge, the velocity anomaly zones indicated by large lateral variations in P-wave velocity $\left(5.2-6.2 \mathrm{~km} \mathrm{~s}^{-1}\right)$ and laterally high anomaly of Poisson's ratio (0.02 - 0.04) in the upper crust and thick crust (thickening southward from $9-12 \mathrm{~km})$ were found below the Huatung Basin and the Western Trough of the Gagua Ridge. Abrupt crustal thickening northward east of the ridge may be related to northwestward convergence of the Philippine Sea Plate. These velocity anomaly zones in the upper crust at both sides of the ridge might result from deformed, fractured or faulted zones. These zones support $\mathrm{E}-\mathrm{W}$ compression, $\mathrm{N}-\mathrm{S}$ shearing (or transpression) and uplifting that may have also created the Gagua Ridge and crustal thickening west of the ridge.
\end{abstract}

Key words: Crustal velocity structures, Four-component OBS data, Gagua Ridge, Poisson's Ratio, Transpression

Citation: Deng, J. M., T. K. Wang, T. R. Chen, C. S. Lee, and C. S. Liu, 2014: Crustal velocity structures imaged from four-component OBS data across the southern Gagua Ridge in the western Philippine Sea. Terr. Atmos. Ocean. Sci., 25, 755-773, doi: 10.3319/TAO.2014.08.28.01(T)

\section{INTRODUCTION}

The Gagua Ridge, with a length of about $300 \mathrm{~km}$ and a maximum height of $4 \mathrm{~km}$ above the seafloor, runs along $123^{\circ} \mathrm{E}$ and is the largest ridge in the western Philippine Sea (Fig. 1). This linear oceanic ridge separates the Huatung Basin off SE Taiwan from the oceanic crust of the West Philippine Basin (Murauchi et al. 1968). Fracture zones near the Gagua Ridge, northwestward extending to the Taitung Canyon (Sibuet et al. 2004), are similar to those ridges with fracture zones in the North Atlantic (Detrick et al. 1993), the South Ocean (Collot et al. 1995), the Central Pacific (Kruse et al. 1996) and the East Pacific Rise (Begnaud et al. 1997). The Gagua Ridge formation in the western Philippine Sea and how the Gagua Ridge relates to the origins of Huatung Basin and West Philippine Basin have been the focal points

\footnotetext{
* Corresponding author

E-mail: tkwang@mail.ntou.edu.tw
}

of several investigations. The Gagua Ridge subduction beneath the Ryukyu Arc started probably 0.7 - 0.6 Ma based on marine observations and the kinematic data (Dominguez et al. 1998). The Gagua Ridge formation may has resulted from fracture zones (Karig and Wageman 1975), extinct spreading ridge (Bowin et al. 1978), uplift of oceanic crust (Mrozowski et al. 1982) or an old subduction zone (Evans and Lewis 1984). The Gagua Ridge was most likely formed due to a change of spreading direction and Philippine Sea Plate reorganization at about $45 \mathrm{Ma}$ (Hilde and Lee 1984; Hall et al. 1995). This hypothesis posits that the Gagua Ridge may have formed due to strike-slip deformation of the West Philippine Basin from the geophysical data (Deschamps and Lallemand 2002). Similarly, the Puysegur Ridge, including over-thrusts and fractures, off south New Zealand in the South Ocean between the Australian and Pacific Plates was formed due to transpression by increasing 
transverse shortening during the southward migration of the Pacific-Australian pole of rotation and possible incipient subduction (Collot et al. 1995; Lebrun et al. 2003).

Crustal models have been constructed for more understanding about the Gagua Ridge. Gravity modeling across the Gagua Ridge (white dotted lines in Fig. 1) indicated thick oceanic crust in the Huatung Basin $(9-12 \mathrm{~km})$, thick ridge root $(17-18 \mathrm{~km})$ and normal oceanic crust in the West Philippine Basin from west to east (Karp et al. 1997; Deschamps et al. 1998). Deschamps et al. (1998) suggested crust beneath the Huatung Basin, formed when the Philippine Sea Plate ceased spreading at $35 \mathrm{Ma}$, over-thrusting the West Philippine Basin eastward. This interpretation is similar to the formation of transverse ridges in Pacific fracture zones as younger-side lithosphere over-thrusting older-side lithosphere (McCarthy et al. 1996). On the other hand, the former fracture zones near the Gagua Ridge may have behaved as a transpressive plate boundary during oblique compression and the Philippine Sea Plate reorganization so that the Huatung Basin is thick due to compression and belongs to a different and older (8 - 16 m.y.) plate than the Philippine Sea Plate (Sibuet et al. 1998).

A deep seismic survey conducted in 1995 using air guns from R/V Maurice Ewing and 13 ocean-bottom seismometers (OBS) deployed from R/V Ocean Researcher 1, as shown by black lines and black circles in Fig. 1, imaged crustal thickness of the Huatung Basin $(7 \mathrm{~km})$ and a forearc block west of the northern Luzon Arc (Yang and Wang 1998; Wang et al. 2001; McIntosh et al. 2005). Normal thickness of the Huatung Basin as an oceanic crust north of $22^{\circ} \mathrm{N}$ may indicate less compression from collision between the Luzon Arc and the Eurasia Continent than that south of it (Sibuet et al. 2002). The upper part of the Luzon arc accreted against the Ryukyu forearc while its lower part subducted beneath Eurasia (Sibuet et al . 2004). Similarly, based on long-offset $(4.5 \mathrm{~km})$ reflection seismic data collected by the R/V Maurice Ewing in 1995, northward subduction of the Gagua Ridge beneath the Ryukyu Trench with a steeper dip in the Philippine Sea Plate east of the Gagua Ridge was observed (Schnürle et al. 1998a).

Neither gravity modeling (Karp et al. 1997; Deschamps et al. 1998) nor deep seismic survey (Yang and Wang 1998; Schnürle et al. 1998a; Wang et al. 2001; McIntosh et al. 2005) near the Gagua Ridge revealed whether the Huatung Basin over-thrust the West Philippine Basin and the reason why crustal structures of Huatung Basin and West Philippine Basin are different. In this paper, seismic imaging of crustal structures across the southern Gagua Ridge is presented to understand the Gagua Ridge formation, fracture zones west and east of the Gagua Ridge and the oceanic crust of the Huatung Basin and the West Philippine Basin.

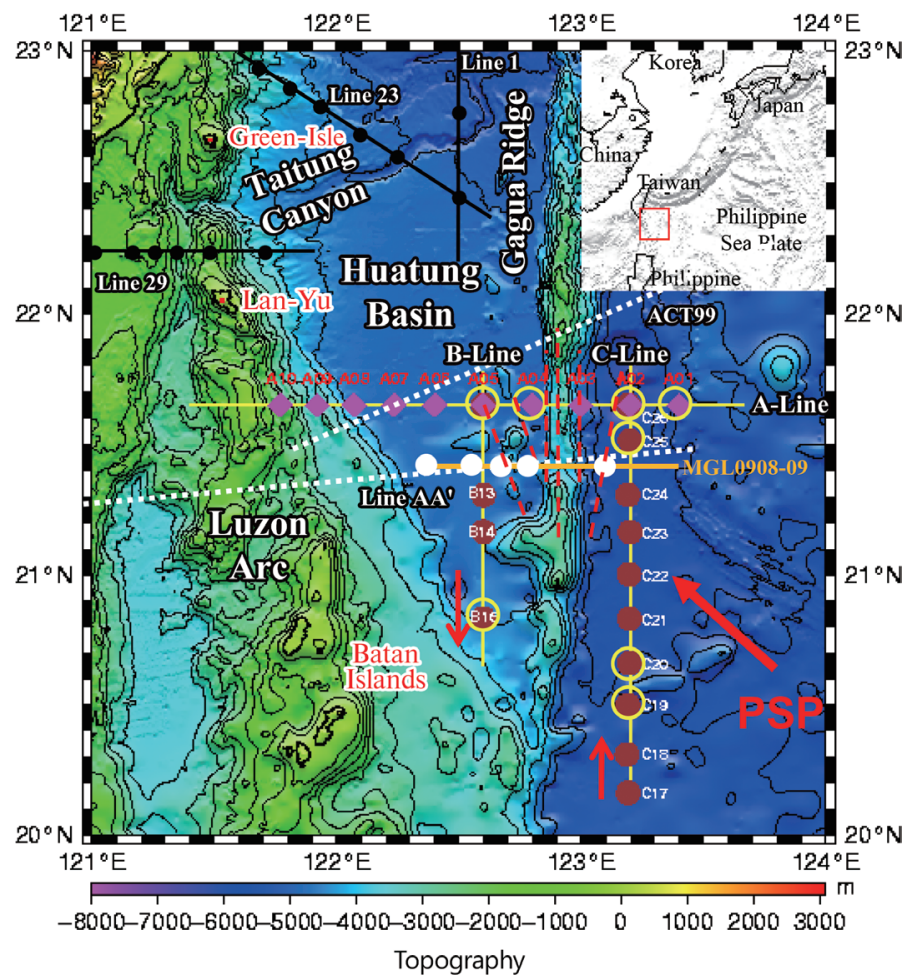

Fig. 1. Bathymetry, deep seismic profiles and tectonic structures across the Gagua Ridge in the western Philippine Sea. Yellow lines are three profiles of 24 OBSs (purple squares and brown circles) collected in 2006. Deep seismic lines and 13 OBSs conducted by R/V Maurice Ewing in 1995 are indicated by black lines and black circles, respectively. Gravity profiles along ACT99 (Deschamps et al. 1998) and line AA' (Karp et al. 1997) are marked by white dashed lines. Red dashed lines and red solid arrows indicated the fracture zones and the convergent directions based on the OBS models, respectively. Data recorded from OBS stations, as indicated by yellow circles, were shown in Figs. 2 - 5. 


\section{METHOD}

\subsection{OBS Survey}

A deep seismic survey used portable ocean-bottom seismometers (MicrOBS), air-gun shots and a 6-channel streamer, and acquired across the southern Gagua Ridge $200 \mathrm{~km}$ off SE Taiwan was conducted in September of 2006. We deployed 10 MicrOBSs (Auffret et al. 2004) along an E - W A-Line from the West Philippine Basin westward across the Gagua Ridge and Huatung Basin ending at the Luzon Arc (Fig. 1). Four MicrOBSs were also deployed along an N - S B-Line, $30 \mathrm{~km}$ west of the Gagua Ridge. The R/V Ocean Researcher I, with an air-gun volume of 900 cubic inches and a shooting interval of about $20 \mathrm{~s}$, shot through the A-Line and B-Line. We observed the refracted and reflected waves traveling through the sedimentary layers (Figs. 2a and b). The first arrivals of refraction through the crust can be observed from the OBS data along the A-Line and B-Line at offsets of 5 - $40 \mathrm{~km}$ (Figs. 3 and 4). Since these first arrivals were interfered with the previous shot noise (PSN as shown in Figs. 3 and 4), we increased the air-gun volume and shooting interval to 1000 cubic inches and $30 \mathrm{~s}$, respectively, with imaging along an $\mathrm{N}-\mathrm{S} C$-Line with 10 MicrOBSs at $20 \mathrm{~km}$ east of the Gagua Ridge (Fig. 1). This improvement leads to appearance of the first arrivals without interference by the PSN through the upper mantle at offsets of 5 - $50 \mathrm{~km}$ (Fig. 5).

Strong current and the deep bathymetry (depth of 22 stations $>4000 \mathrm{~m}$ as shown in Fig. 1) in the western Philippine Sea caused most of the MicrOBSs to drift from their deployed location. Travel times and their gradients of the direct waves shot from the air guns recorded at OBS (Wang et al. 2007) were used to relocate 24 MicrOBSs with maximum shifts of about $400 \mathrm{~m}$ (OBS A01) along the shot track and of about $1000 \mathrm{~m}$ perpendicular to the seismic line (Table 1). The greater shifts from the OBS deployment perpendicular to the profile (bold faces in Table 1) may be due to the relocation uncertainty based only on shots along the profile. Initial data processing, such as band-pass filtering $(2-5-40-50 \mathrm{~Hz})$ and amplitude correction over the offset, was also applied.

\subsection{P-Wave Velocity Modeling}

Initial models were constructed from reflection times of the multi-channel seismic data along the three OBS profiles (A-Line, B-Line, and C-Line), the density models (white dashed lines in Fig. 1) inverted from gravity data along ACT99 (Deschamps et al. 1998) and Line AA' (Karp et al. 1997), and the P-wave velocity models along OBS lines 1, 23, 29 (black lines in Fig. 1) of 1995 TAICRUST experiment (Yang and Wang 1998; Wang et al. 2001; McIntosh et al. 2005) and along MGL0908-09 of 2009 TAIGER experiment (Mirza 2012). Three (upper, lower, and compacted) sedimentary layers and three (upper, middle, and lower) crustal layers were included in these OBS models.
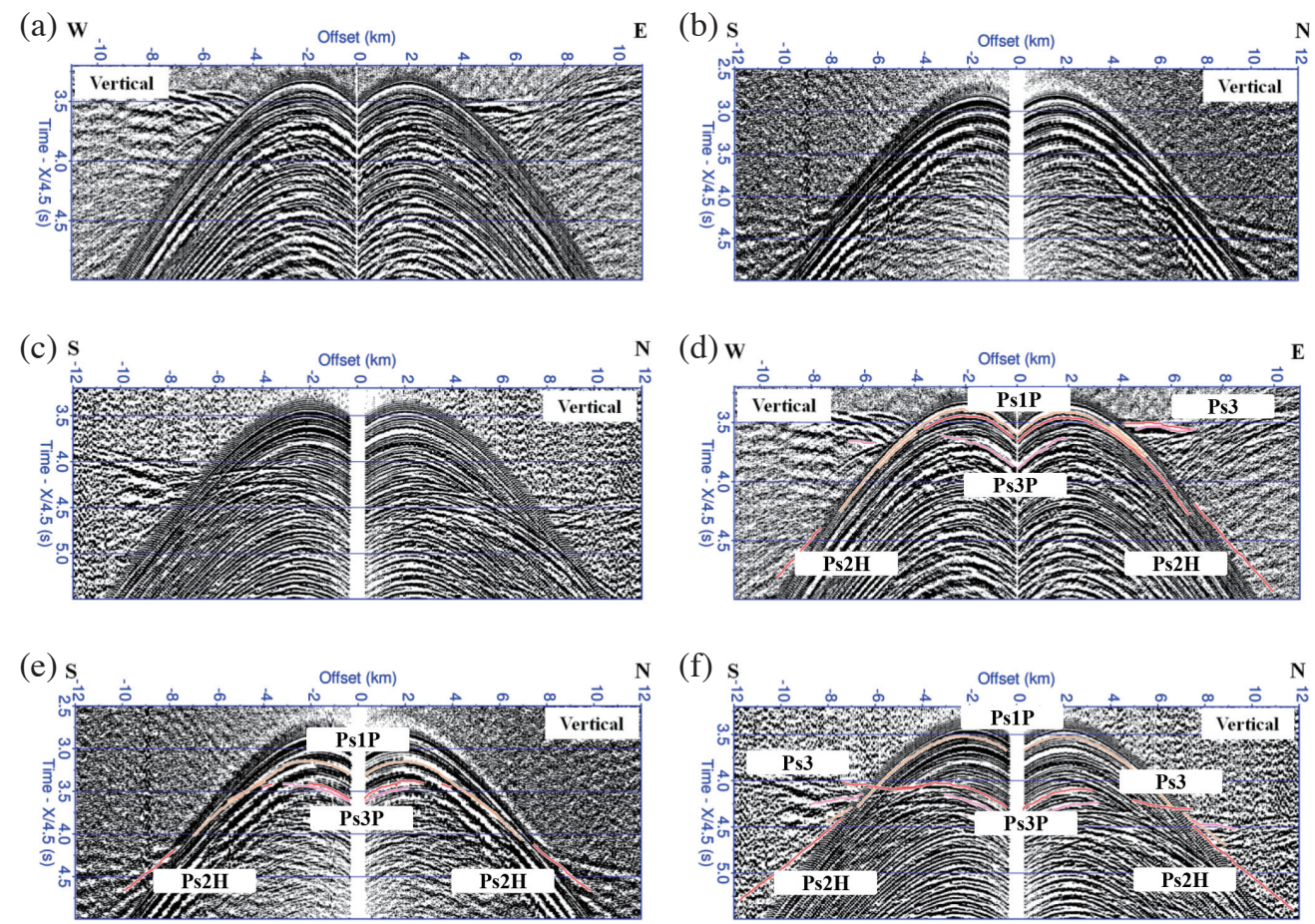

Fig. 2. Vertical component of OBS data from (a) A01, (b) B16, and (c) C19. Picked head-wave, refracted and reflected arrivals of the sediments superimposed on the vertical component of OBS data from (d) A01, (e) B16, and (f) C19. Ps*P: arrivals reflected at the intra-sedimentary interfaces . Picked head-wave, refracted and reflected arrivals of the sediments superimposed on the Ps*: arrivals refracted through sediments. Ps*H: head-wave arrivals traveling through the top of sedimentary layers. 

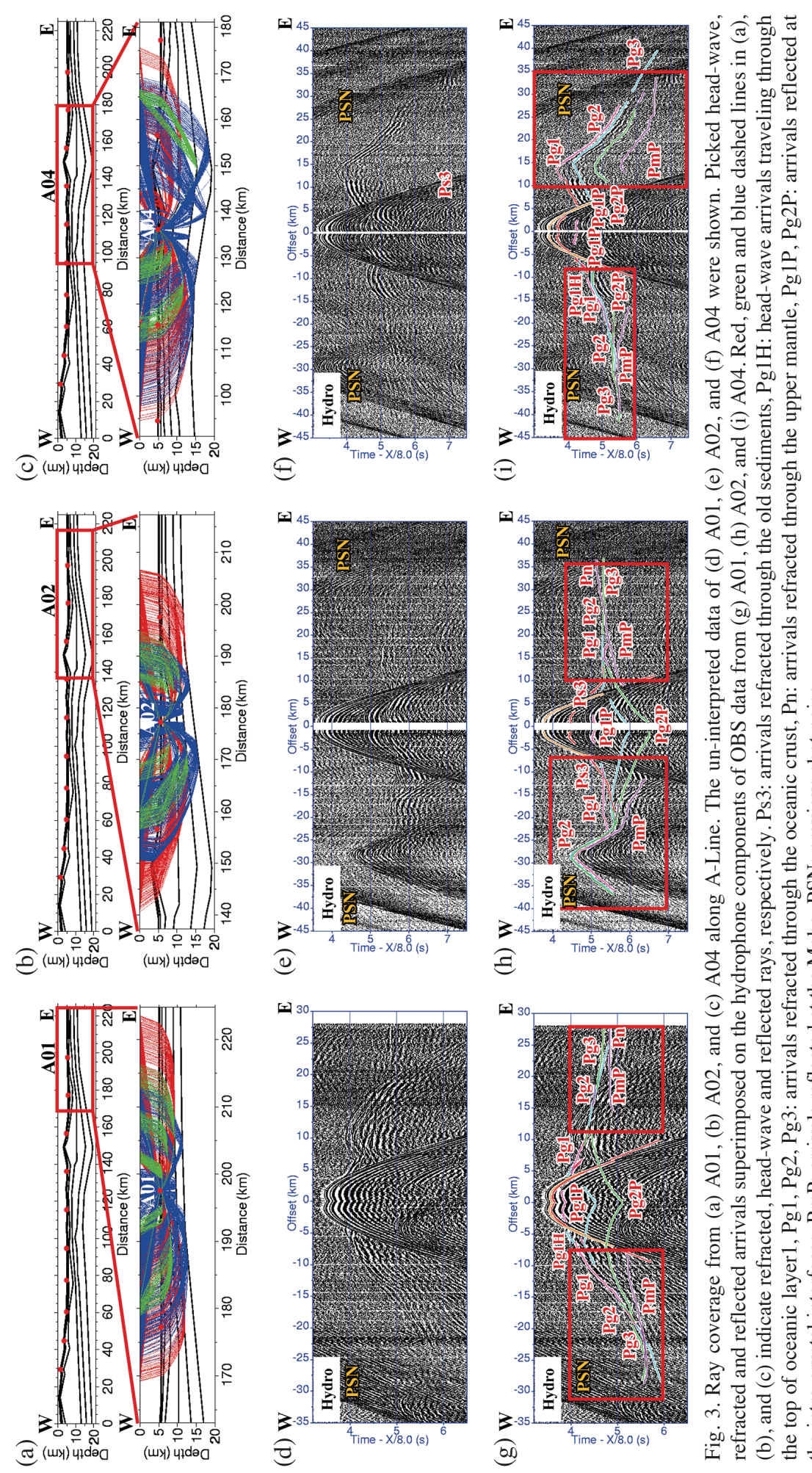

(2) ती

定文믕

包司完

푸일

跣

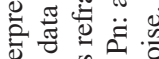

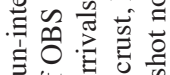

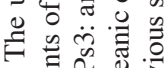

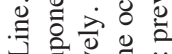

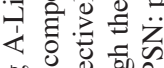

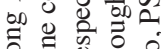

근을

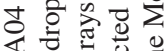

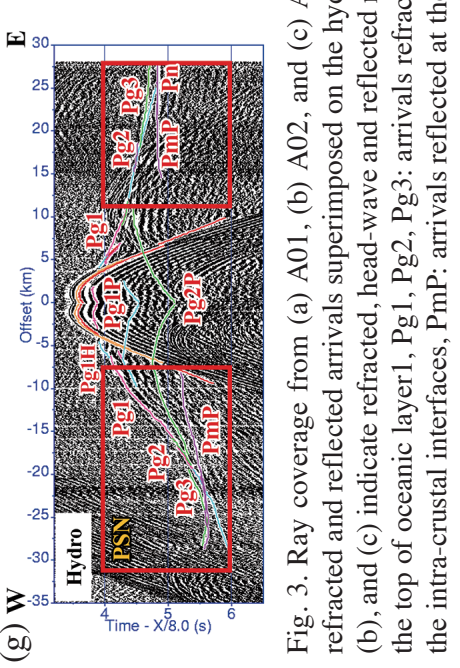



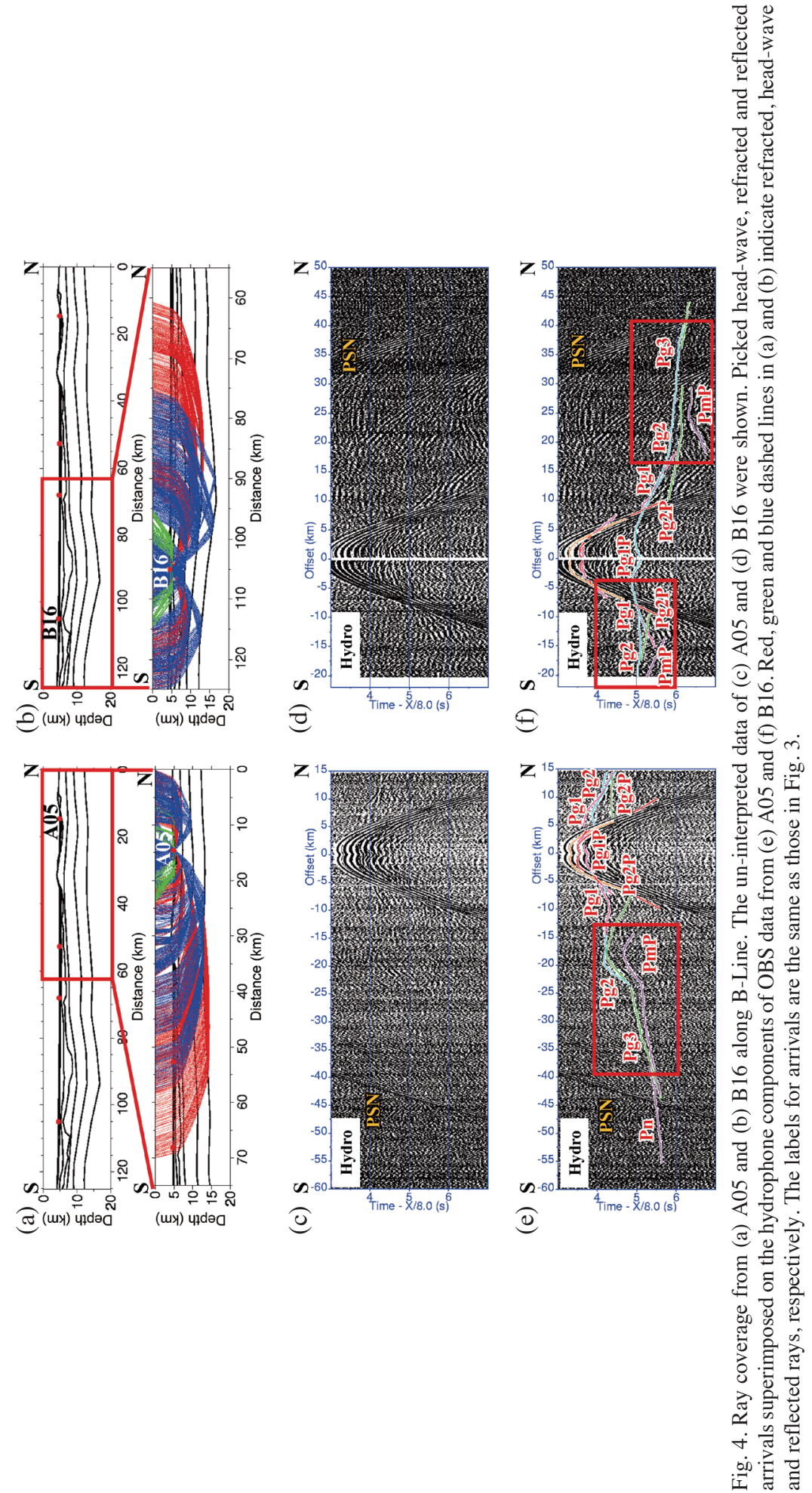

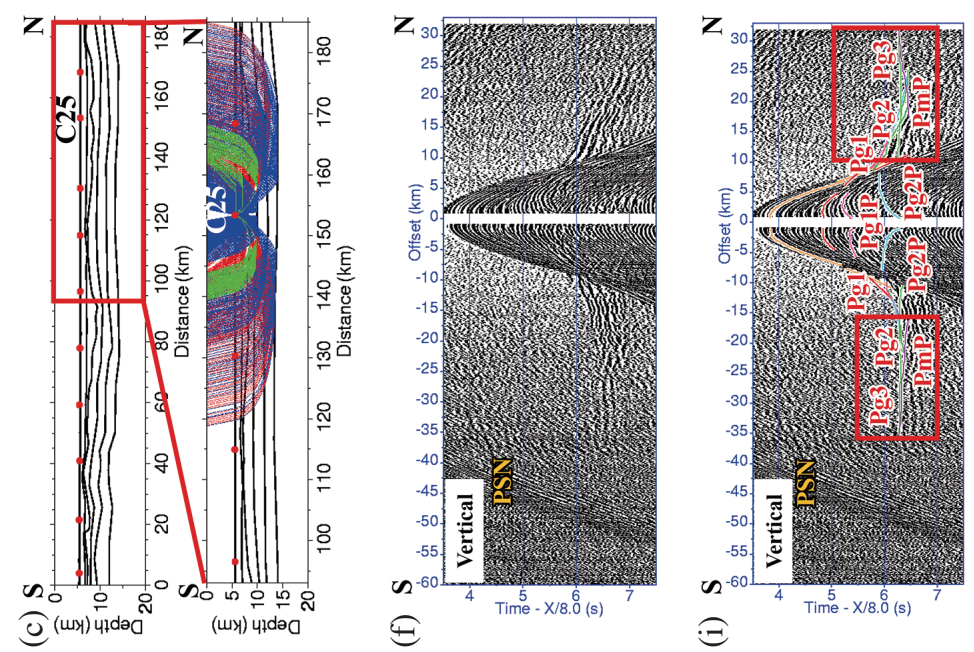

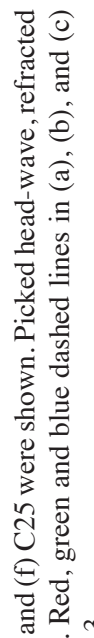
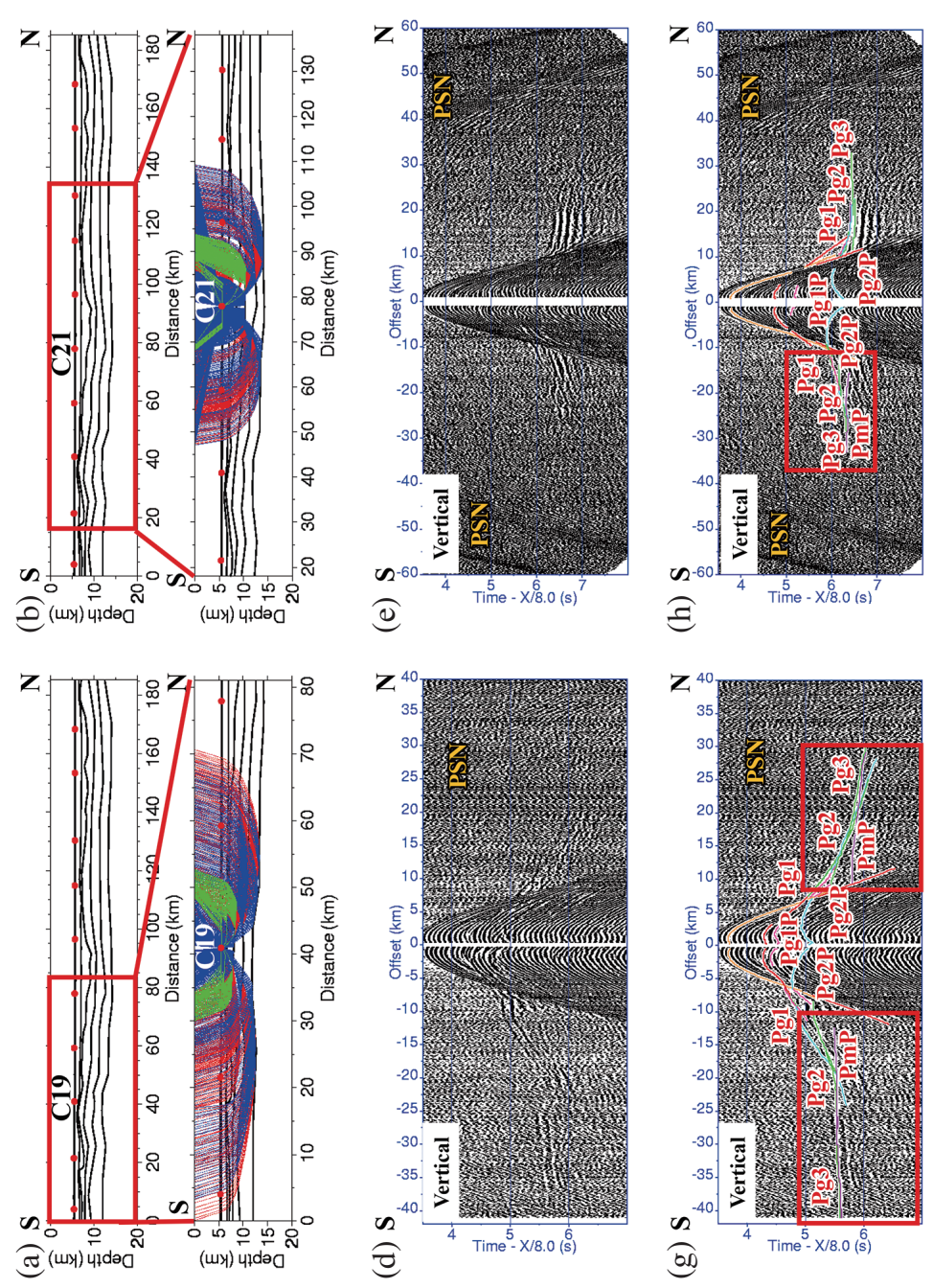

तิ

(2)

ค릉

ขे है

능 己

营

प्ठ

我 的

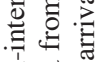

छ胥

Fथ $थ$

.

Uं

bo

ฮุ

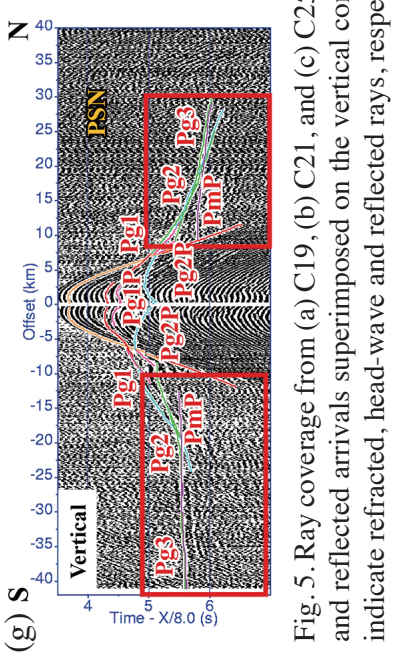


Table 1. OBS relocation along (a) A-Line, (b) B-Line, and (c) C-Line.

(a)

\begin{tabular}{ccccccccccc}
\hline OBS Station & $\mathbf{A 1 0}$ & $\mathbf{A 0 9}$ & $\mathbf{A 0 8}$ & $\mathbf{A 0 7}$ & $\mathbf{A 0 6}$ & $\mathbf{A 0 5}$ & $\mathbf{A 0 4}$ & $\mathbf{A 0 3}$ & $\mathbf{A 0 2}$ & A01 \\
\hline Deployment Longitude & 121.7699 & 121.9199 & 122.0701 & 122.2348 & 122.3999 & 122.5999 & 122.8 & 122.9989 & 123.1998 & 123.3986 \\
Deployment Latitude & 21.6500 & 21.6500 & 21.6500 & 21.6500 & 21.6500 & 21.6500 & 21.6501 & 21.6486 & 21.65 & 21.6483 \\
Shift (m) Along Profile & 17 & -54 & -63 & -24 & -20 & 21 & -166 & -151 & 125 & 429 \\
Shift (m) Vertical Profile & 4 & 7 & 5 & 601 & 836 & 22 & 283 & 987 & 852 & 9 \\
Relocation Longitude & 121.7701 & 121.9193 & 122.0695 & 122.235 & 122.4001 & 122.6015 & 122.8014 & 122.9991 & 123.1986 & 123.3945 \\
Relocation Latitude & 21.6498 & 21.6500 & 21.6500 & 21.6554 & 21.6564 & 21.6495 & 21.6525 & 21.6589 & 21.6577 & 21.6499 \\
Water Depth (m) & 1336 & 3269 & 4583 & 4837 & 4840 & 4862 & 4907 & 4724 & 5620 & 5377 \\
\hline
\end{tabular}

(b)

\begin{tabular}{ccccc}
\hline OBS Station & A05 & B13 & B14 & B16 \\
\hline Deployment Longitude & 122.5999 & 122.5999 & 122.5999 & 122.5997 \\
Deployment Latitude & 21.3059 & 21.3059 & 21.1666 & 20.8331 \\
Shift (m) Along Profile & 60 & 55 & 231 & 55 \\
Shift (m) Vertical Profile & 7 & 104 & 789 & 280 \\
Relocation Longitude & 122.5998 & 122.5990 & 122.5924 & 122.5970 \\
Relocation Latitude & 21.6494 & 21.3064 & 21.1687 & 20.8335 \\
Water Depth (m) & 4732 & 4787 & 4746 & 4502 \\
\hline
\end{tabular}

(c)

\begin{tabular}{ccccccccccc}
\hline OBS Station & $\mathbf{C 1 7}$ & $\mathbf{C 1 8}$ & $\mathbf{C 1 9}$ & $\mathbf{C 2 0}$ & $\mathbf{C 2 1}$ & $\mathbf{C 2 2}$ & $\mathbf{C 2 3}$ & $\mathbf{C 2 4}$ & C25 & C26 \\
\hline Deployment Longitude & 123.1996 & 123.1999 & 123.1999 & 123.2008 & 123.1996 & 123.2001 & 123.2003 & 123.2010 & 123.1998 & 123.2001 \\
Deployment Latitude & 20.1663 & 20.3247 & 20.5001 & 20.6661 & 20.8494 & 20.9994 & 21.1769 & 21.3069 & 21.5156 & 21.6501 \\
Shift (m) Along Profile & 88 & 20 & 49 & 41 & 31 & 32 & 85 & 74 & 48 & 172 \\
Shift (m) Vertical Profile & 899 & 958 & 320 & 134 & 899 & 335 & 365 & 249 & 905 & 361 \\
Relocation Longitude & 123.1910 & 123.1908 & 123.1969 & 123.1988 & 123.1909 & 123.1998 & 123.1968 & 123.1986 & 123.1912 & 123.1965 \\
Relocation Latitude & 20.1671 & 20.3249 & 20.5004 & 20.6658 & 20.8344 & 21.0023 & 21.1685 & 21.3076 & 21.5161 & 21.6517 \\
Water Depth (m) & 5398 & 5417 & 5512 & 5550 & 5594 & 5616 & 5624 & 5628 & 5624 & 5617 \\
\hline
\end{tabular}

Reduction velocities of 4.5 and $8 \mathrm{~km} \mathrm{~s}^{-1}$ were used for displaying OBS arrivals through the sediment (Fig. 2) and the crust (Figs. 3 - 6), respectively. P-wave arrivals of refraction and reflection were identified from the hydrophone and vertical components of OBS data at the same time before arrival picking. However, most of the reflected P-wave arrivals were identified sensitively on the vertical component of OBS data whereas most of the refracted P-wave arrivals were picked readily on the hydrophone component of OBS data. Generally, we picked head-wave $\left(\mathrm{Ps}^{*} \mathrm{H}, \mathrm{Pg} * \mathrm{H}\right)$ and refracted (Ps*, $\mathrm{Pg}^{*}, \mathrm{Pn}$ ) arrivals, where s, g, and * stand for sediment, crust and the layer number in the sediment or the crust, from the hydrophone component of OBS data (Figs. 3d - i, 4c - f) to constrain the velocities along the models. The depth of the interfaces along the models can be determined based on re- flected (Ps*P, Pg*P) arrivals usually identified from the vertical component of OBS data (Figs. 2, 5d - i, 6).

Velocity models were subsequently modified by reducing travel-time errors (Zelt and Smith 1992) layer-bylayer from the uppermost layer down to the lowermost layer (Wang et al. 2006). Although the RMS travel-time errors from the lower crust $(\mathrm{Pg} 3)$, Moho (PmP) and mantle (Pn) along the A-Line (Table 2a) and B-Line (Table 2b) were less than $0.1 \mathrm{~s}$, coverage of refracted rays and reflection points too sparse (Fig. 7) to constrain all. Large uncertainties in the Moho depths below the Gagua Ridge along A-Line are observed due to the few constraints of the lower crustal velocity. However, the total travel-time errors for the sediment and the crust are less than 0.05 and $0.1 \mathrm{~s}$, respectively (Table 2). Normal-incident travel times of reflections, computed from 


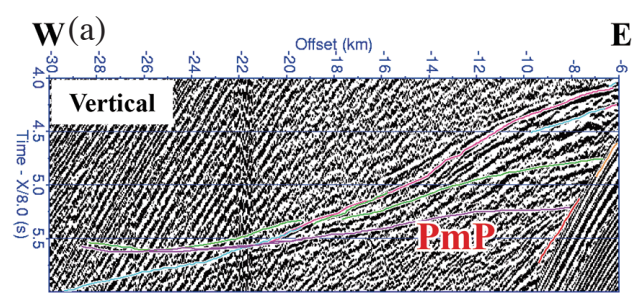

E $\quad \mathbf{W}(\mathrm{b})$

$\mathbf{E}$

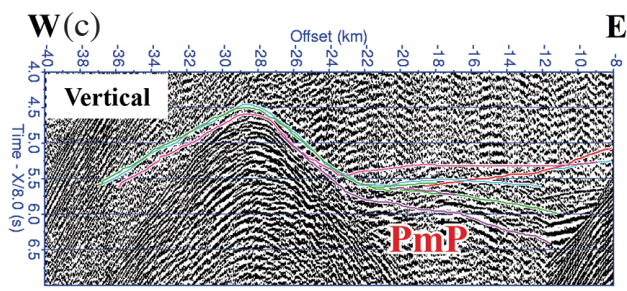

E W(d)

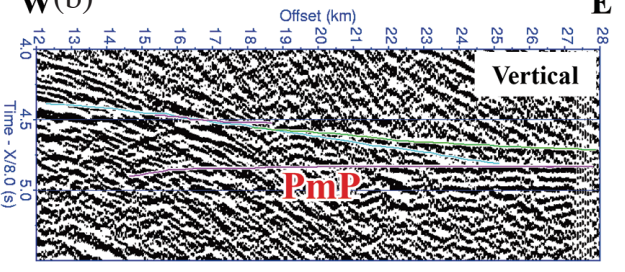

W(e)
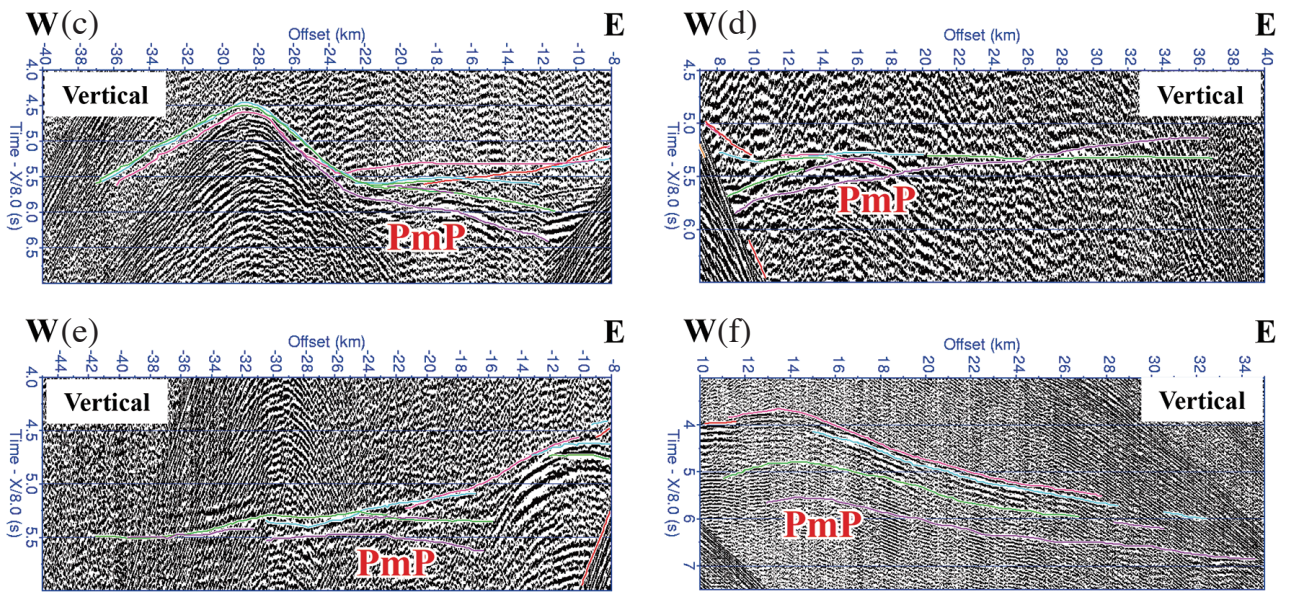

E W(f)

$\mathbf{E}$
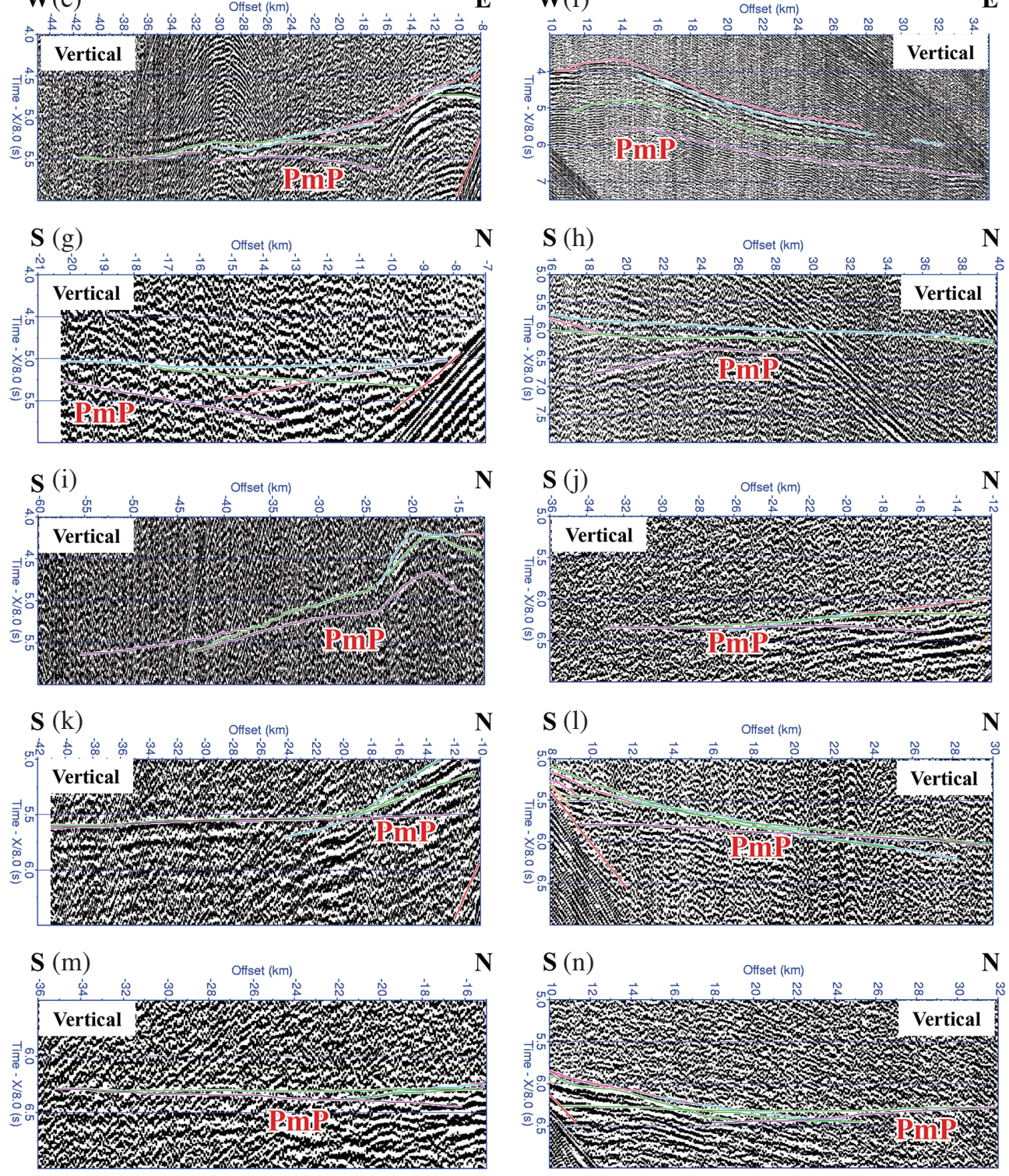

Fig. 6. The travel-time picking of PmP signal superimposed on the vertical component of data from (a) West and (b) East side of OBSA01, (c) West and (d) East side of OBSA02, (e) West and (f) East side of OBSA04 along A-Line; (g) South and (h) North side of OBSB16, (i) South side of OBSC21, (j) South side of OBSA05 along B-Line; (k) South and (l) North side of OBSC19, (m) South and (n) North side of OBSC25 along C-Line. PmP: arrivals reflected at the Moho. 
Table 2. RMS travel-time residual (ms) for P-wave arrivals at each station along (a) A-Line, (b) B-Line, and (c) C-Line. Travel-time errors of $30-50 \mathrm{~ms}$ and greater than $50 \mathrm{~ms}$ are denoted by blue and red colors, respectively.

(a)

\begin{tabular}{|c|c|c|c|c|c|c|c|c|c|c|c|c|c|c|c|c|c|c|c|c|}
\hline OBS Station & \multicolumn{2}{|c|}{ A10 } & \multicolumn{2}{|c|}{ A09 } & \multicolumn{2}{|c|}{ A08 } & \multicolumn{2}{|c|}{ A07 } & \multicolumn{2}{|c|}{ A06 } & \multicolumn{2}{|c|}{ A05 } & \multicolumn{2}{|c|}{ A04 } & \multicolumn{2}{|c|}{ A03 } & \multicolumn{2}{|c|}{ A02 } & \multicolumn{2}{|c|}{ A01 } \\
\hline Location $(\mathrm{km})$ & & & & & 60 & & & & & & 115 & & & & 156 & & & & & .55 \\
\hline Phase & W & $\mathrm{E}$ & W & $\mathrm{E}$ & W & $\mathrm{E}$ & W & $\mathrm{E}$ & W & $\mathrm{E}$ & $\mathrm{W}$ & $\mathrm{E}$ & W & $\mathrm{E}$ & W & $\mathrm{E}$ & W & $\mathrm{E}$ & W & $\mathrm{E}$ \\
\hline Ps1P & 19 & 29 & 26 & 10 & 11 & 23 & 6 & 12 & 26 & 34 & 23 & 39 & 11 & 25 & 13 & 14 & 27 & 29 & 14 & 16 \\
\hline Ps2H & - & 23 & 19 & 12 & 16 & 8 & 16 & 15 & 24 & 22 & 26 & 25 & 10 & - & - & - & - & 6 & 13 & 17 \\
\hline Ps2 & 18 & 12 & - & 25 & - & 6 & 12 & 4 & 2 & 5 & 7 & 21 & 7 & 18 & - & - & - & - & 24 & 8 \\
\hline Ps2P & 7 & 4 & 23 & 23 & 29 & 26 & 19 & 15 & 11 & 19 & 28 & 23 & 18 & 19 & - & - & 14 & 17 & 14 & 16 \\
\hline Ps $3 \mathrm{H}$ & 18 & 11 & 8 & 18 & 25 & 16 & 6 & 9 & 1 & 2 & 7 & 12 & 20 & 15 & 18 & 4 & 3 & 6 & 22 & 16 \\
\hline Ps3 & 24 & 45 & 13 & 29 & 39 & 23 & 28 & 18 & 17 & 7 & - & 15 & 34 & 29 & - & 30 & 22 & 11 & 4 & 20 \\
\hline Ps3P & - & 13 & 21 & 31 & 9 & 16 & 21 & 18 & 8 & 19 & 11 & 18 & 19 & 30 & 3 & 12 & 27 & 20 & 17 & 11 \\
\hline $\mathrm{Pg} 1 \mathrm{H}$ & 34 & 28 & - & 13 & 28 & 26 & 20 & 26 & - & 36 & 32 & 60 & 69 & - & 75 & 31 & 29 & 48 & 37 & 15 \\
\hline $\mathrm{Pg} 1$ & 9 & 23 & 18 & 40 & 33 & 47 & 64 & 55 & 73 & 72 & 29 & 34 & 35 & 71 & 64 & 16 & 44 & 19 & 41 & 37 \\
\hline $\mathrm{Pg} 1 \mathrm{P}$ & - & 23 & 17 & 21 & 29 & 47 & 38 & 32 & 19 & 18 & 31 & 12 & 41 & 51 & 29 & 14 & 54 & 33 & 33 & 39 \\
\hline $\mathrm{Pg} 2 \mathrm{H}$ & - & 9 & - & 28 & 9 & - & 13 & 15 & 12 & 8 & - & - & 22 & - & - & 27 & 4 & 5 & 7 & 20 \\
\hline Pg2 & - & 15 & - & 42 & 63 & 38 & 19 & 65 & 67 & 57 & 20 & 61 & 69 & 32 & 75 & 18 & 53 & 58 & 21 & 18 \\
\hline $\mathrm{Pg} 2 \mathrm{P}$ & - & - & 12 & 15 & 22 & 4 & 22 & 13 & 10 & 11 & 14 & 56 & 42 & 31 & 29 & 13 & 12 & 11 & 30 & 28 \\
\hline $\mathrm{Pg} 3$ & - & 13 & - & 12 & - & 22 & 36 & 22 & 18 & 54 & 15 & 30 & 22 & - & 30 & - & 26 & 15 & 30 & 19 \\
\hline $\mathrm{PmP}$ & - & 14 & - & 17 & 35 & 14 & 15 & 11 & 8 & 16 & 16 & 34 & 28 & 40 & 26 & 13 & 21 & 10 & 30 & 47 \\
\hline $\mathrm{Pn}$ & - & - & - & - & - & - & - & 23 & - & 16 & - & 29 & - & - & 15 & - & - & 29 & 44 & 69 \\
\hline
\end{tabular}

(b)

\begin{tabular}{c|r|r|r|r|r|r|r|r}
\hline OBS Station & \multicolumn{2}{|c|}{ A05 } & \multicolumn{2}{|c|}{ B13 } & \multicolumn{2}{|c|}{ B14 } & \multicolumn{2}{|c}{ B16 } \\
\hline Location $(\mathrm{km})$ & \multicolumn{1}{|c|}{14.56} & \multicolumn{2}{|c|}{52.68} & 68.09 & \multicolumn{2}{|c}{105.05} \\
\hline Phase & \multicolumn{1}{c|}{ S } & N & \multicolumn{1}{c|}{ S } & N & S & N & \multicolumn{1}{c}{ S } & N \\
\hline Ps1P & 19 & 22 & 14 & 13 & 17 & 10 & 18 & 18 \\
Ps2H & 16 & - & 15 & 6 & 25 & 19 & 11 & 15 \\
Ps2 & 14 & 4 & 8 & 17 & 9 & 5 & 9 & 15 \\
Ps2P & 18 & 12 & 17 & 31 & 2 & 7 & 12 & 6 \\
Ps3H & 21 & 27 & 15 & 9 & 21 & 12 & - & - \\
Ps3 & 8 & 18 & 5 & 12 & 10 & 7 & 14 & 22 \\
Ps3P & 6 & 28 & 8 & 24 & 19 & 8 & 8 & 19 \\
Pg1H & 57 & 54 & 49 & 30 & 52 & 46 & 62 & 99 \\
Pg1 & 61 & 54 & 49 & 35 & 57 & 44 & 65 & 99 \\
Pg1P & 52 & 37 & 55 & 66 & 75 & 42 & 37 & 39 \\
Pg2H & 83 & 16 & 66 & 8 & 41 & 41 & 88 & 89 \\
Pg2 & 74 & 15 & 30 & 24 & 51 & 19 & 32 & 84 \\
Pg2P & 16 & 9 & 10 & 9 & 18 & 29 & 7 & 6 \\
Pg3 & 42 & - & 22 & 26 & 41 & - & - & 46 \\
PmP & 45 & - & 13 & 38 & 16 & 13 & 27 & 64 \\
Pn & 43 & - & 14 & - & - & - & - & - \\
\hline
\end{tabular}


Table 2. (Continued)

(c)

\begin{tabular}{|c|c|c|c|c|c|c|c|c|c|c|c|c|c|c|c|c|c|c|c|c|}
\hline OBS Station & \multicolumn{2}{|c|}{ C17 } & \multicolumn{2}{|c|}{ C18 } & \multicolumn{2}{|c|}{ C19 } & \multicolumn{2}{|c|}{$\mathrm{C2O}$} & \multicolumn{2}{|c|}{$\mathrm{C21}$} & \multicolumn{2}{|c|}{$\mathrm{C22}$} & \multicolumn{2}{|c|}{$\mathrm{C23}$} & \multicolumn{2}{|c|}{$\mathrm{C24}$} & \multicolumn{2}{|c|}{$\mathrm{C25}$} & \multicolumn{2}{|c|}{$\mathrm{C26}$} \\
\hline Location $(\mathrm{km})$ & & & & & 40 & & & & 77 & & & & & & 130 & & 153 & & 168 & \\
\hline Phase & $\mathrm{S}$ & $\mathrm{N}$ & $\mathrm{S}$ & $\mathrm{N}$ & S & $\mathrm{N}$ & $\mathrm{S}$ & $\mathrm{N}$ & $\mathrm{S}$ & $\mathrm{N}$ & $\mathrm{S}$ & $\mathrm{N}$ & $\mathrm{S}$ & $\mathrm{N}$ & $\mathrm{S}$ & $\mathrm{N}$ & S & $\mathrm{N}$ & $\mathrm{S}$ & $\mathrm{N}$ \\
\hline Ps1P & 24 & 31 & 29 & 31 & 27 & 13 & 26 & 13 & 22 & 23 & 5 & 5 & 26 & 20 & 15 & 26 & 15 & 27 & 19 & 23 \\
\hline $\mathrm{Ps} 2 \mathrm{H}$ & - & 12 & - & 23 & 13 & 20 & 10 & 10 & 28 & 18 & 26 & 25 & 20 & 28 & 25 & 19 & - & 30 & 20 & 22 \\
\hline Ps2 & - & 10 & 7 & 16 & 3 & 11 & 7 & 23 & 14 & 14 & 13 & 25 & 13 & 14 & 7 & 16 & 11 & 11 & 15 & 16 \\
\hline $\mathrm{Ps} 2 \mathrm{P}$ & 12 & 17 & 16 & 15 & 17 & 21 & 18 & 12 & 11 & 18 & 28 & 25 & 32 & 28 & 14 & 17 & 28 & 25 & 28 & 20 \\
\hline Ps $3 \mathrm{H}$ & - & 14 & 26 & 22 & 13 & 20 & 22 & 9 & - & - & - & 17 & 24 & 25 & 21 & 24 & - & 18 & 6 & 19 \\
\hline Ps3 & - & 6 & 6 & 12 & 2 & 8 & 11 & 28 & 12 & 5 & 43 & 16 & 8 & 13 & 9 & 12 & 37 & 31 & 24 & 17 \\
\hline Ps $3 \mathrm{P}$ & 14 & 10 & 25 & 26 & 21 & 12 & 19 & 14 & 34 & 37 & 11 & 14 & 31 & 40 & 22 & 10 & 47 & 27 & 14 & 44 \\
\hline $\mathrm{Pg} 1 \mathrm{H}$ & - & 31 & - & - & - & 28 & 23 & 41 & - & 54 & 36 & - & 40 & 19 & 67 & 32 & 24 & - & 66 & - \\
\hline $\mathrm{Pg} 1$ & - & 12 & 21 & 59 & 62 & 12 & 12 & 35 & 11 & 48 & 28 & 89 & 69 & 42 & 58 & 8 & 30 & 36 & 21 & 55 \\
\hline $\mathrm{Pg} 1 \mathrm{P}$ & 5 & 4 & 17 & 43 & 6 & 16 & 14 & 15 & 34 & 34 & 14 & 22 & 23 & 38 & 32 & 54 & 50 & 28 & 17 & 18 \\
\hline $\mathrm{Pg} 2 \mathrm{H}$ & - & - & - & 55 & - & 48 & 29 & 39 & 23 & 62 & - & - & - & - & 47 & 35 & 39 & - & - & 23 \\
\hline $\operatorname{Pg} 2$ & - & 39 & 20 & 7 & 60 & 30 & 5 & 21 & 6 & 31 & 21 & 13 & 15 & 14 & 6 & 11 & 21 & 13 & 26 & 12 \\
\hline $\mathrm{Pg} 2 \mathrm{P}$ & - & 18 & 13 & 19 & 12 & 9 & 16 & 7 & 7 & 14 & 15 & 9 & 15 & 7 & 12 & 8 & 6 & 12 & 18 & 8 \\
\hline $\mathrm{Pg} 3$ & - & 62 & 35 & 8 & 44 & 10 & 15 & 11 & 8 & 6 & 13 & 9 & 15 & 8 & 10 & 8 & 13 & 11 & 16 & 9 \\
\hline $\mathrm{PmP}$ & - & 95 & 72 & 10 & 33 & 9 & 34 & 11 & 5 & 16 & 70 & 15 & 10 & 12 & 19 & 15 & 8 & 25 & 24 & 17 \\
\hline Pn & - & 88 & - & 8 & 23 & - & 46 & 72 & - & - & - & - & - & - & - & - & - & - & - & - \\
\hline
\end{tabular}

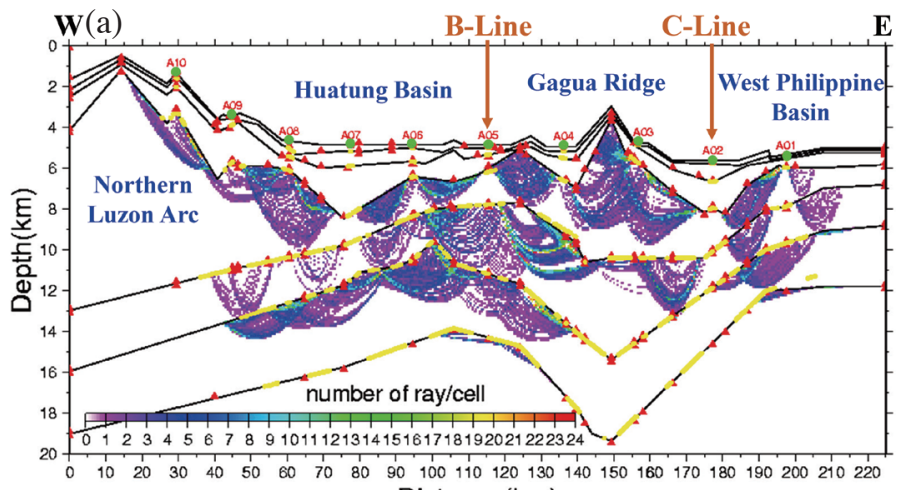
Distance $(\mathrm{km})$

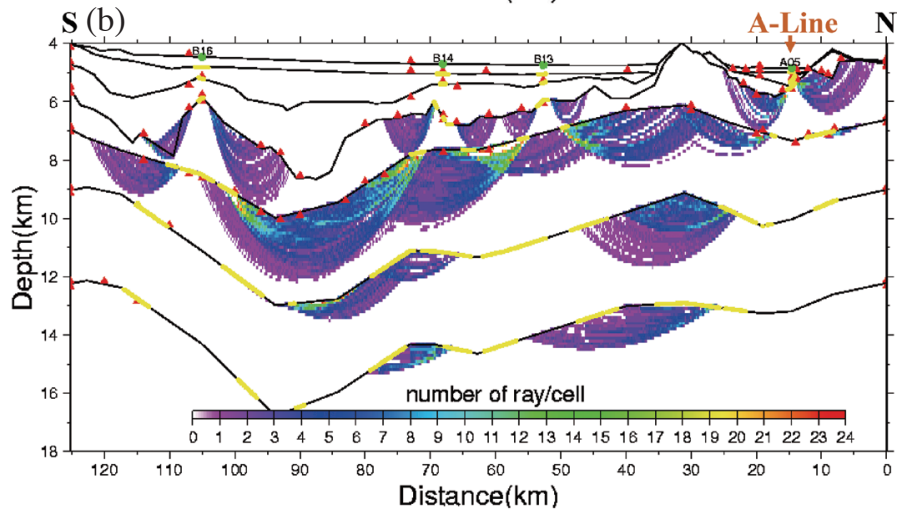

Fig. 7. Density of the refracted rays traveling through their deepest layers along (a) A-Line, (b) B-Line, and (c) C-Line around South of the Gagua Ridge. Dimension of the cell for counting the ray number is $0.5 \mathrm{~km}$ along the distance and $0.1 \mathrm{~km}$ along the depth. OBS locations and velocity nodes are denoted by green circles and red triangles, respectively. Most reflected arrivals were used to invert only model interfaces while velocity nodes for the models are fixed. Thus, model interfaces are constrained by reflection points as indicated by yellow points. 


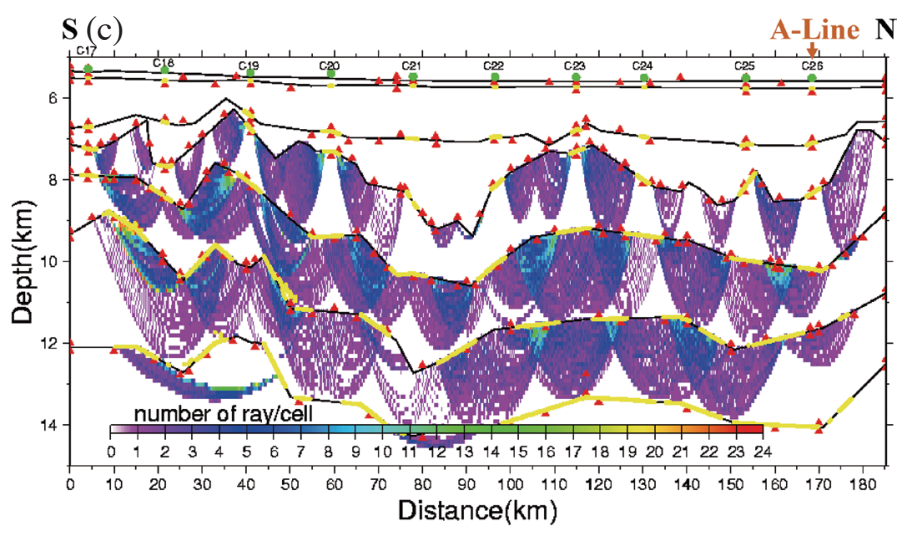

Fig. 7. (Continued)

the OBS velocity models (Operto 1996), were consistent with the time-migrated section (Fig. 8). Eventually, we constructed P-wave velocity models with coverage of headwave, refracted and reflected rays.

This method allows more velocity nodes in the model with high-density refracted rays however the velocity nodes were removed from the model with low-density refracted rays. Similarly, we can add or remove interface nodes based on more or less reflection points at the model interfaces, respectively. Therefore, the minimum number of velocity nodes is demonstrated by refracted ray density whereas the minimum number of interface nodes is justified by reflection points onto the model interfaces along the A-Line, B-Line, and C-Line (Fig. 7). In particular, refracted rays through the oceanic crust along the C-Line east of the Gagua Ridge (Fig. 7c) were denser than those along two other lines due to the large shooting interval (about $30 \mathrm{~s}$ ) and thinner crust (about $7 \mathrm{~km}$ ) along the C-Line. The model reveals good constraints of the oceanic crust as deep as the Moho across and east of the Gagua Ridge.

\subsection{Poisson's Ratio Modeling}

Poisson's ratio in each layer of initial models was taken from Poisson's ratio models along lines 1 and 23 (black lines in Fig. 1) of 1995 TAICRUST experiment (Wang and Pan 2001). We also considered P - S waves converted 2 times at 4 different interfaces (seafloor, basement, and two intracrustal interfaces) to select the converted shear-wave phases (Wang and Pan 2001; Zhao et al. 2010).

We used both the sea floor and the sediment's basement as PS converted boundaries (Fig. 9) because they are better constrained in the P-wave modeling (Deng et al. 2008). Reflected shear waves propagating through the upper (Ss1S) and lower (Ss2S) sediments converted only at the sea floor were considered. Three kinds of converted arrivals, one of them only converted when transmitted at the sea floor (Ss3S) and one PS mode-converted when reflected at the sedimentary basement (Ps3S), were chosen in two horizontal components of OBS data (Fig. 10).

Refracted arrivals through the crust converted at intracrustal interfaces ( $\mathrm{Pg} 2-\mathrm{Sg} 1$ and $\mathrm{Pg} 3-\mathrm{Sg} 2$ in Fig. 10) were observed in contrast to using reflected arrivals of converted waves propagating in sediment. These converted refractions appear as the first arrivals at offsets of $5-27 \mathrm{~km}$ in two horizontal components of OBS data (Fig. 10). Other shear-wave conversions through the crust were also tested. However, these converted waves are neither distinguished from horizontal components of OBS data nor constrained from the crustal Poisson's ratio. Since two horizontal components of the OBS data were also affected by PSN at offsets of about $30 \mathrm{~km}$ (Fig. 10), the S-wave phases travelling in the lower crust are difficult to observe.

A lateral variation in Poisson's ratio can be inverted from constructing blocky models of Poisson's ratio in each layer. Poisson's ratios constrained from the shear waves can be derived by reducing travel-time errors of the converted shear waves layer-by-layer (less than $90 \mathrm{~ms}$ in Table 3) from the initial models.

\section{RESULTS AND DISCUSSION}

Owing to the limitation of using small air-guns $\left(<1000 \mathrm{in}^{3}\right)$ and short shooting intervals $(\sim 20 \mathrm{~s})$, we could not properly image the lower crustal structure across the Gagua Ridge (A-Line, Fig. 11a) and along the Huatung Basin (B-Line, Fig. 11b). P-wave velocity and Poisson's ratio constrained by OBS data still revealed how the Gagua Ridge was formed and what tectonic characteristics existed after its formation.

Velocity anomaly zones, one below the summit of the Gagua Ridge and the others beneath two toes of the Gagua Ridge (OBSA04 and OBSA03), in the upper crust were observed from large lateral variations in P-wave velocity of $5.5-6.4 \mathrm{~km} \mathrm{~s}^{-1}$ (red dashed lines in Fig. 11a) and low velocity of $4.5-5.0 \mathrm{~km} \mathrm{~s}^{-1}$ (below OBSA04 in Fig. 11a). However, the 
velocity anomaly zone at the Gagua Ridge summit along the A-Line was identified only from the P-wave velocity model owing to the lack of constraint in the Poisson's ratio model. These velocity anomaly zones may have been generated when the Gagua Ridge was formed by the oblique compression and plate reorganization of the Philippine Sea Plate.

After the Gagua Ridge was formed between the Huatung Basin and the West Philippine Basin, the crustal structure west of the Gagua Ridge thickened (10 km thick across A-Line in Fig. 11a). Crustal thickening below the Huatung Basin may be partially due to compression as indicated by velocity anomaly zones in the upper crust. Velocity anomaly zones in the upper crust with large lateral velocity variations of $5.2-6.2 \mathrm{~km} \mathrm{~s}^{-1}$ below OBSA06, $5.4-6.2 \mathrm{~km} \mathrm{~s}^{-1}$ below A05, and $5.0-6.2 \mathrm{~km} \mathrm{~s}^{-1}$ near the Western Trough (Fig. 11a), were imaged below the Huatung Basin. Velocity anomaly zones imaged by the P-wave modeling (red dashed lines in Fig. 11a) were also supported by a relatively high Poisson's ratio of about 0.305 (0.01 - 0.02 laterally high) in the upper crust (black dashed lines in Fig. 12a).

The middle and lower crust below the Huatung Basin, with high P-wave velocities of $6.8-7.6 \mathrm{~km} \mathrm{~s}^{-1}$ (a blue dashed frame in Fig. 11a) and a low Poisson's ratio of 0.28 (a blue dashed frame in Fig. 12a), might be interpreted as possible igneous rocks. However, we did not rule out magma (Deschamps et al. 1998) or underplating (Wang et al. 2006). On the eastern flanks of the Luzon Arc (below OBSA08), we also found low P-wave velocities of $4.5-5.0 \mathrm{~km} \mathrm{~s}^{-1}$ (a
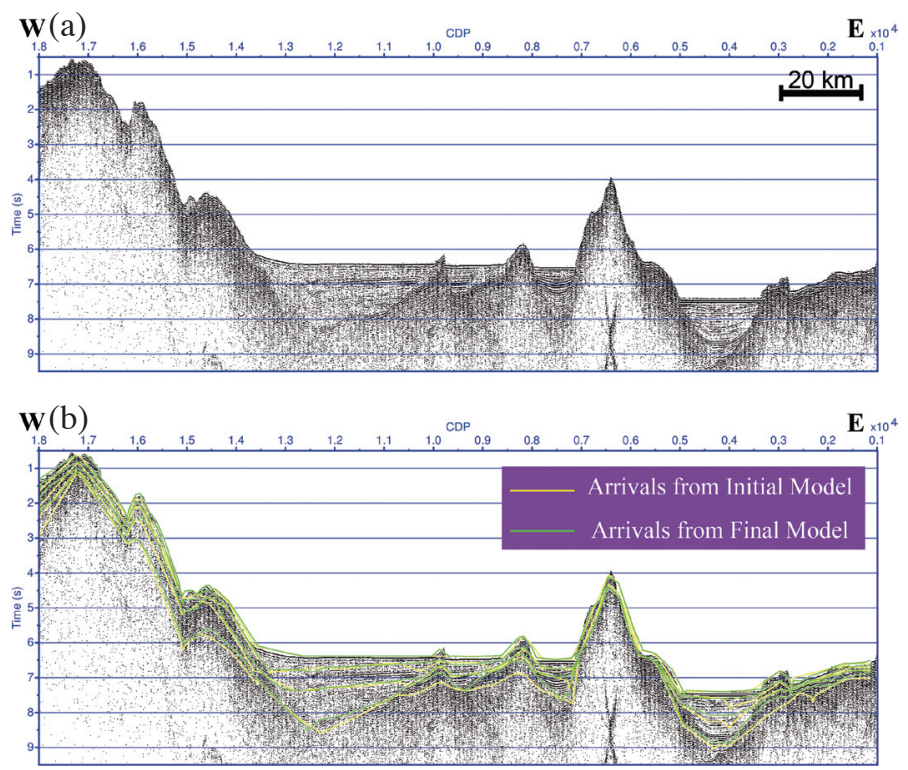

Fig. 8. (a) A time-migrated section along A-Line across the southern Gagua Ridge. (b) Calculated reflected travel-times at the zero offset based on an OBS velocity model along A-Line superimposed on the time-migrated section across the southern Gagua Ridge.

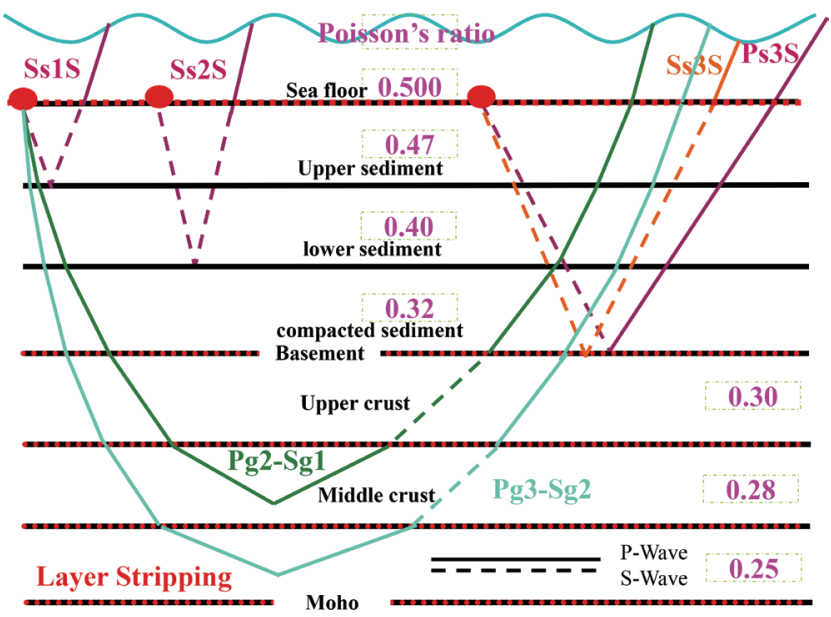

Fig. 9. Choice of the converted shear waves. The seafloor, basement, intra-crustal interfaces and the Moho were set as the converted interfaces (black and red dashed lines). OBSs are indicated by red circles. 

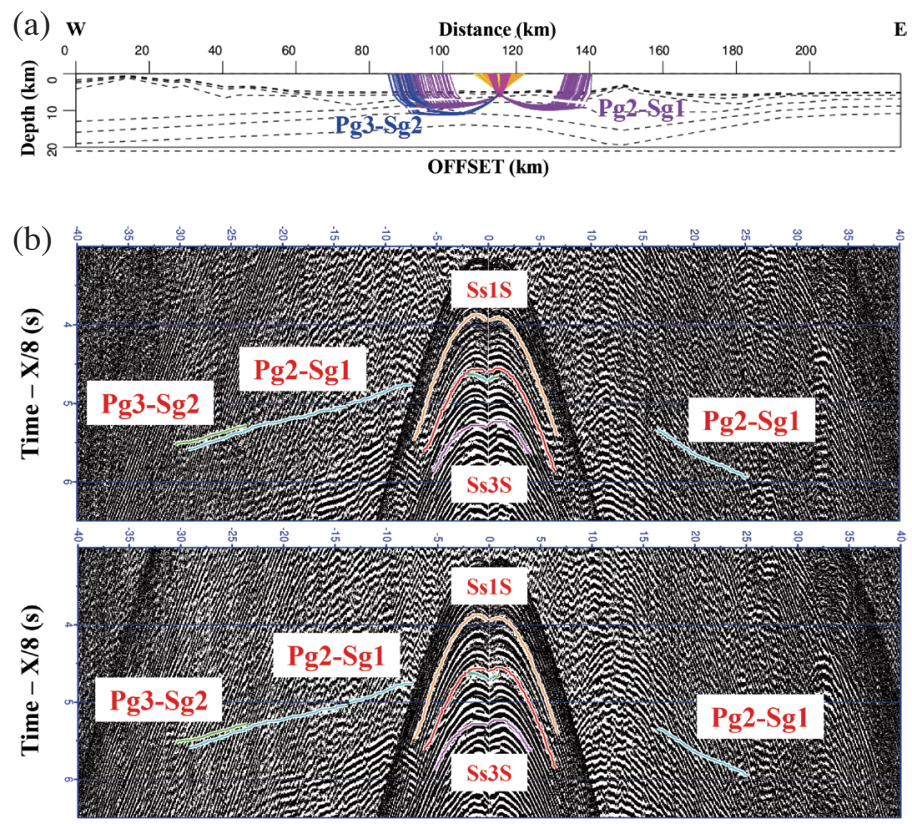

Fig. 10. (a) Ray coverage from OBSA05 along A-Line. (b) Picked head-wave, refracted and reflected arrivals of the converted shear wave were superimposed on two horizontal components of OBS data from OBSA05. The phases of the converted shear waves were shown as Fig. 9.

Table 3. RMS travel-time residual (ms) for converted shear arrivals at each station along (a) A-Line, (b) B-Line, and (c) C-Line. Travel-time errors of $30-50 \mathrm{~ms}$ and greater than $50 \mathrm{~ms}$ are denoted by blue and red colors, respectively. (a)

\begin{tabular}{|c|c|c|c|c|c|c|c|c|c|c|c|c|c|c|c|c|c|c|c|c|}
\hline OBS Station & \multicolumn{2}{|c|}{ A10 } & \multicolumn{2}{|c|}{ A09 } & \multicolumn{2}{|c|}{ A08 } & \multicolumn{2}{|c|}{ A07 } & \multicolumn{2}{|c|}{ A06 } & \multicolumn{2}{|c|}{ A05 } & \multicolumn{2}{|c|}{ A04 } & \multicolumn{2}{|c|}{ A03 } & \multicolumn{2}{|c|}{ A02 } & \multicolumn{2}{|c|}{ A01 } \\
\hline Location $(\mathrm{km})$ & \multicolumn{2}{|c|}{29.38} & \multicolumn{2}{|c|}{44.83} & \multicolumn{2}{|c|}{60.50} & \multicolumn{2}{|c|}{77.50} & \multicolumn{2}{|c|}{94.60} & \multicolumn{2}{|c|}{115.44} & \multicolumn{2}{|c|}{136.14} & \multicolumn{2}{|c|}{156.60} & \multicolumn{2}{|c|}{177.26} & \multicolumn{2}{|c|}{197.55} \\
\hline Phase & W & $\mathrm{E}$ & W & $\mathrm{E}$ & W & $\mathrm{E}$ & W & $\mathrm{E}$ & W & $\mathrm{E}$ & W & $\mathrm{E}$ & W & E & W & $\mathrm{E}$ & W & $\mathrm{E}$ & W & $\mathrm{E}$ \\
\hline Ss1S & 17 & 10 & 17 & 26 & 34 & - & 54 & 43 & 12 & 17 & 18 & 24 & 41 & 44 & 17 & 18 & 16 & 11 & 32 & 30 \\
\hline Ss $2 S$ & 16 & 17 & 9 & 25 & 30 & - & 39 & 58 & 38 & 17 & 26 & 14 & 40 & 28 & 48 & 42 & 29 & 33 & 29 & 26 \\
\hline Ss3S & & & & & & & & & & & & & & & & & & & & \\
\hline Ps3S & 7 & 7 & 40 & 13 & 22 & 89 & 44 & 54 & 12 & 6 & 20 & 27 & 3 & 35 & 34 & 17 & 12 & 17 & 27 & 34 \\
\hline Ss3P & & & & & & & & & & & & & & & & & & & & \\
\hline $\mathrm{Pg} 2-\mathrm{Sg} 1$ & - & - & - & - & - & - & 22 & 14 & 21 & 65 & 67 & 20 & - & 66 & - & - & - & - & 29 & 53 \\
\hline $\mathrm{Pg} 3-\mathrm{Sg} 2$ & - & - & - & - & - & - & - & - & - & - & - & 26 & - & - & - & - & - & - & - & 16 \\
\hline
\end{tabular}

(b)

\begin{tabular}{c|r|r|c|c|c|c|c|c}
\hline OBS Station & \multicolumn{2}{|c|}{ A05 } & \multicolumn{2}{|c|}{ B13 } & \multicolumn{2}{c|}{ B14 } & \multicolumn{2}{|c}{ B16 } \\
\hline Location $(\mathrm{km})$ & \multicolumn{2}{|c|}{14.56} & \multicolumn{2}{c|}{52.68} & \multicolumn{2}{c}{68.09} & \multicolumn{2}{|c}{105.02} \\
\hline Phase & S & N & S & N & S & N & S & N \\
\hline Ss1S & 9 & 17 & 34 & 36 & 31 & 32 & 52 & 28 \\
Ss2S & 41 & 7 & 41 & 33 & 38 & 6 & 37 & 30 \\
Ss3S & & & & & & & & \\
Ps3S & 6 & 23 & 33 & 67 & 20 & - & 26 & 37 \\
Ss3P & & & & & & & & \\
Pg2 - Sg1 & 44 & 25 & 20 & 18 & 19 & 43 & 30 & 70 \\
Pg3 - Sg2 & 13 & - & 28 & 22 & 24 & 85 & - & 14 \\
\hline
\end{tabular}


Table 3. (Continued)

(c)

\begin{tabular}{|c|c|c|c|c|c|c|c|c|c|c|c|c|c|c|c|c|c|c|c|c|}
\hline OBS Station & \multicolumn{2}{|c|}{ C17 } & \multicolumn{2}{|c|}{ C18 } & \multicolumn{2}{|c|}{ C19 } & \multicolumn{2}{|c|}{$\mathrm{C20}$} & \multicolumn{2}{|c|}{ C21 } & \multicolumn{2}{|c|}{$\mathrm{C} 22$} & \multicolumn{2}{|c|}{$\mathrm{C} 23$} & \multicolumn{2}{|c|}{$\mathrm{C} 24$} & \multicolumn{2}{|c|}{$\mathrm{C} 25$} & \multicolumn{2}{|c|}{$\mathrm{C} 26$} \\
\hline Location $(\mathrm{km})$ & \multicolumn{2}{|c|}{4.05} & \multicolumn{2}{|c|}{21.52} & \multicolumn{2}{|c|}{40.96} & \multicolumn{2}{|c|}{59.26} & \multicolumn{2}{|c|}{77.93} & \multicolumn{2}{|c|}{96.52} & \multicolumn{2}{|c|}{114.92} & \multicolumn{2}{|c|}{130.32} & \multicolumn{2}{|c|}{153.40} & \multicolumn{2}{|c|}{168.42} \\
\hline Phase & $\mathrm{S}$ & $\mathrm{N}$ & $\mathrm{S}$ & $\mathrm{N}$ & $\mathrm{S}$ & $\mathrm{N}$ & $\mathrm{S}$ & $\mathrm{N}$ & $\mathrm{S}$ & $\mathrm{N}$ & $\mathrm{S}$ & $\mathrm{N}$ & $\mathrm{S}$ & $\mathrm{N}$ & S & $\mathrm{N}$ & $\mathrm{S}$ & $\mathrm{N}$ & $\mathrm{S}$ & $\mathrm{N}$ \\
\hline Ss $1 S$ & 13 & 27 & 34 & 70 & 34 & 28 & 35 & 41 & 27 & 23 & 39 & 75 & 20 & 67 & 17 & 20 & 56 & 35 & 41 & 40 \\
\hline Ss2S & 45 & 35 & 29 & 30 & 41 & 14 & 48 & 33 & 58 & 60 & 24 & 28 & 33 & 79 & 40 & 40 & 42 & 16 & 62 & 28 \\
\hline Ss $3 S$ & & & & & & & & & & & & & & & & & & & & \\
\hline Ps3S & 27 & 28 & 38 & 30 & 40 & 26 & 28 & 30 & 63 & 34 & 27 & 32 & 19 & 52 & 43 & 60 & 35 & 37 & 43 & 33 \\
\hline Ss3P & & & & & & & & & & & & & & & & & & & & \\
\hline $\mathrm{Pg} 2-\mathrm{Sg} 1$ & - & 37 & 17 & 33 & 75 & 37 & 55 & 31 & 88 & 6 & 37 & 18 & 52 & 33 & 21 & 33 & 32 & 25 & 24 & 41 \\
\hline $\mathrm{Pg} 3-\mathrm{Sg} 2$ & - & 80 & 19 & 13 & 53 & 6 & 23 & 18 & 17 & 21 & 23 & 10 & 23 & 18 & 20 & 21 & 23 & - & 15 & - \\
\hline
\end{tabular}
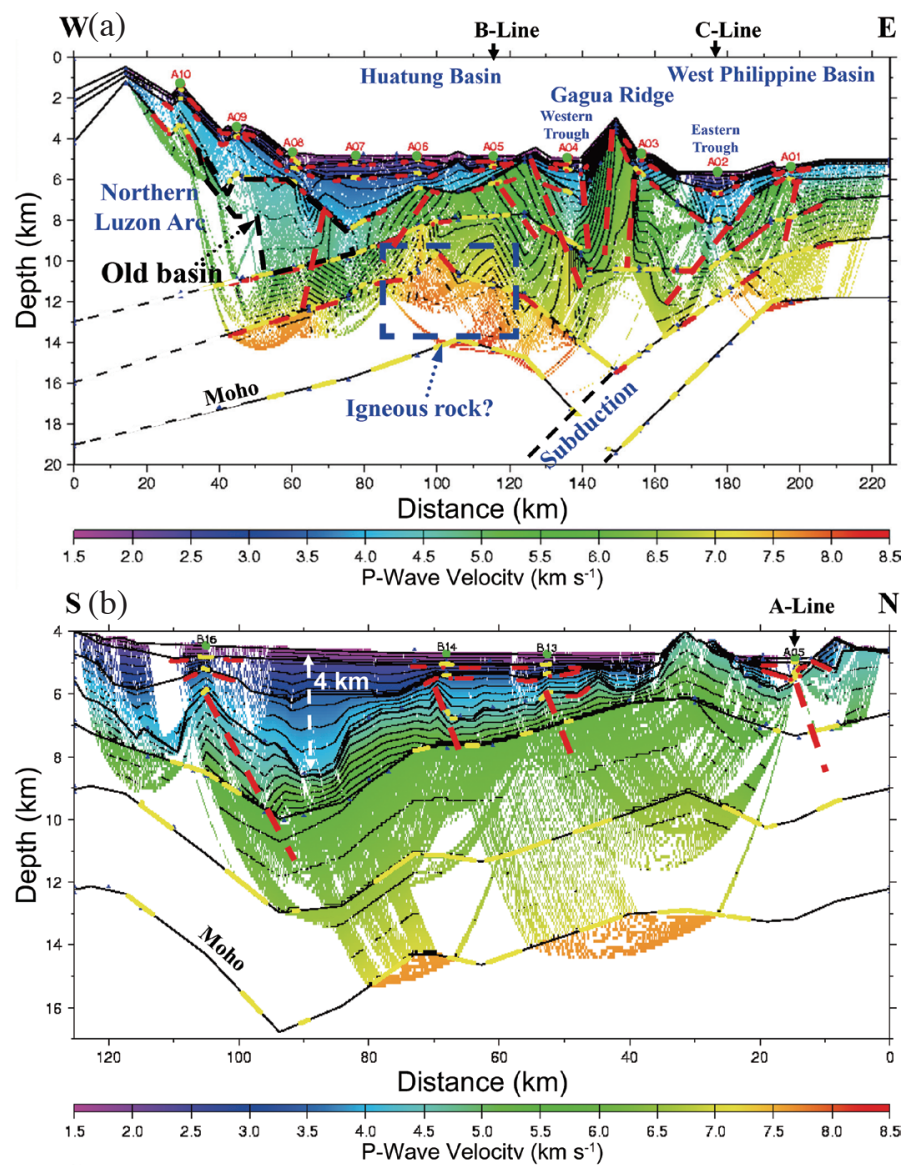

Fig. 11. Velocity-interface model along (a) A-Line, (b) B-Line, and (c) C-Line at the southern portion of the Gagua Ridge covered by refracted rays from OBS/MCS data. OBSs are denoted by green circles. Velocity contour is $0.2 \mathrm{~km} \mathrm{~s}^{-1}$. Velocity nodes and interfaces are blue triangles and black lines, respectively. Model interfaces are constrained from reflection points, as indicated by yellow points, since most of reflected arrivals are used to invert only model interfaces while velocity nodes of the models are fixed. The head waves traveling beneath the layers are indicated by red points. Velocity anomaly zones are illustrated by red dashed lines. 


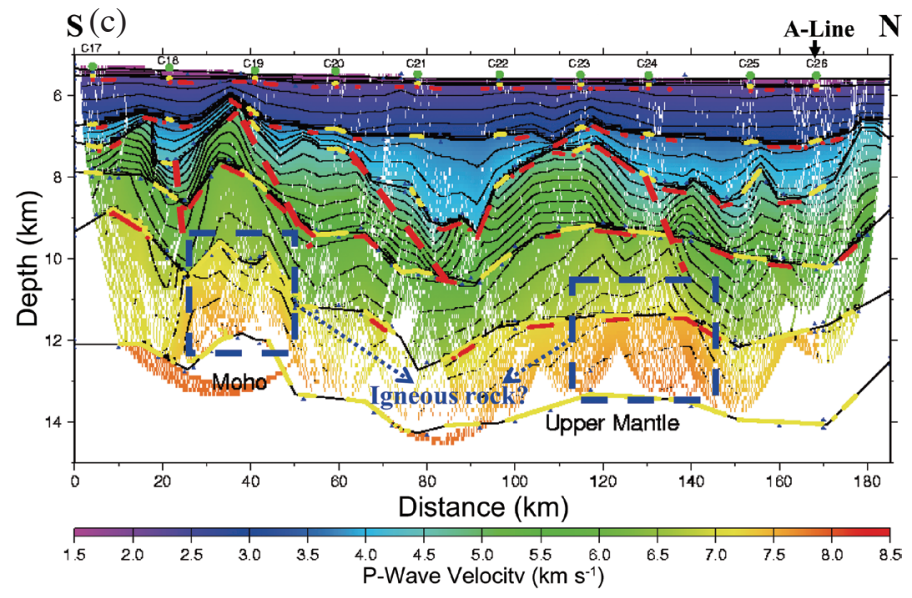

Fig. 11. (Continued)

(a)

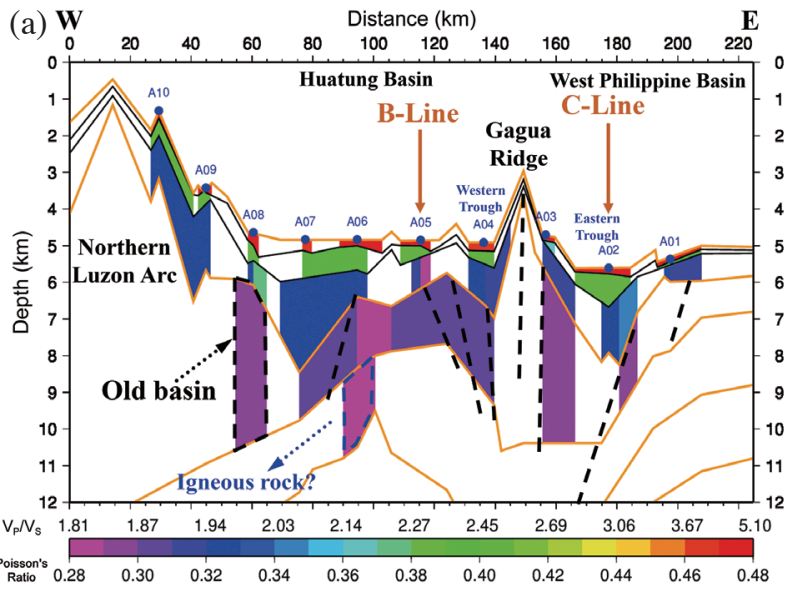

(c) $\mathrm{S}$

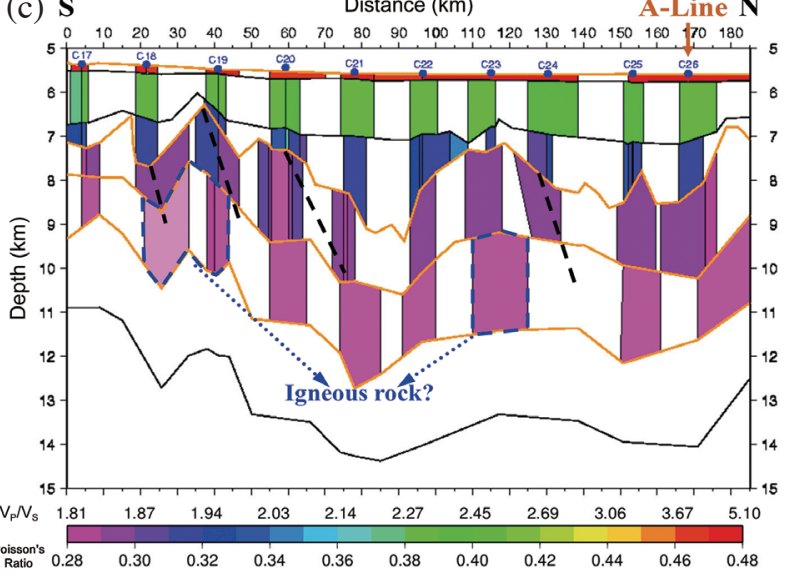

(b) $\mathbf{S}$

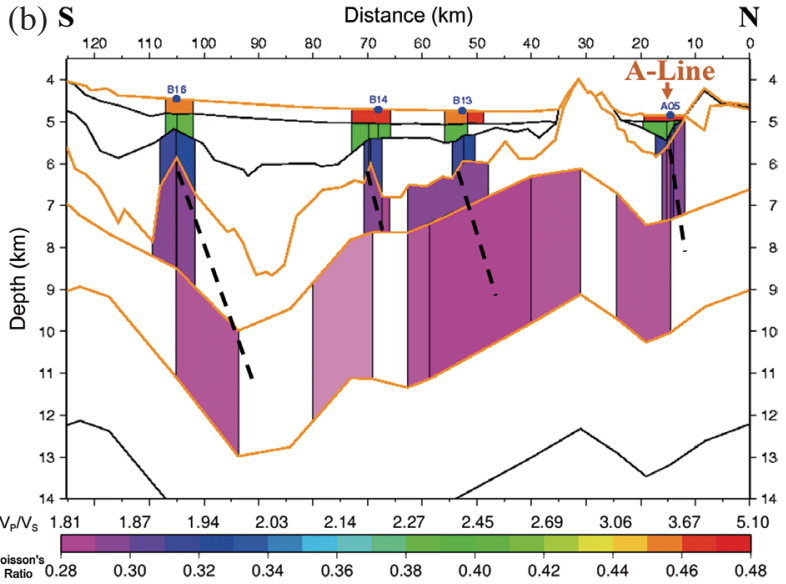

Fig. 12. Modeling of Poisson's ratio along (a) A-Line, (b) B-Line, and (c) C-Line at the southern portion of the Gagua Ridge. OBSs are indicated by blue circles. Colored blocks are constrained by S-wave ray tracing through it. Black and orange lines are layers and converted interfaces, respectively. Velocity anomaly zones, interpreted from P-wave velocity models in Fig. 11, are denoted by black dashed lines. White or colored blocks of the Poisson's ratio indicate without or with passage of shear waves. 
black dashed frame in Fig. 11a) and a relatively high Poisson's ratio of about 0.295 (a black dashed frame in Fig. 12a) in the upper crust. These anomalous P-wave velocity and Poisson's ratio might indicate an old Huatung Basin south of the Ryukyu forearc incorporated into the upper part of the Luzon arc by compression because decoupling in the upper part of the Luzon Arc might have facilitated its accretion against the Ryukyu forearc while its lower part subducted beneath Eurasia (Sibuet et al. 2004).

The crustal structure near the Gagua Ridge might not only be subject to $\mathrm{E}-\mathrm{W}$ compression across the ridge (A-Line) but was also affected by $\mathrm{N}-\mathrm{S}$ shearing parallel to the ridge (B-Line and $\mathrm{C}$-Line). West of the Gagua Ridge, sedimentary thickness of the Huatung Basin increases southward from about $1 \mathrm{~km}$ below OBSB12 to about $4 \mathrm{~km}$ below OBSB14 and OBSB16 (Fig. 11b). Although some of the Moho (yellow points in Fig. 11b) is constrained by PmP arrivals west of the ridge, the crust might be thickening southward along the B-Line (north of the velocity anomaly zone below OBSB16 in Fig. 11b) due to transpression. The velocity anomaly zones were imaged from large lateral velocity variations (4.6 - $6.0 \mathrm{~km} \mathrm{~s}^{-1}$ in Fig. 11b) in the upper crust with relatively high Poisson's ratios (0.295 - 0.305 in Fig. 12b) below OBSB13, OBSB14, OBSB16, and OBSA05. Thus, the velocity anomaly zones at the southern portion of the B-Line and strong lateral crustal velocity and thickness variations could indicate southward shearing (or transpression) west of the ridge (Figs. 1, 11b, 12b), such as the right-lateral strikeslip faulting along the Taitung Canyon identified from faultplane solutions observed in the Huatung Basin (Schnürle et al. 1998b).

East of the Gagua Ridge, sedimentary thickness of the West Philippine Basin increases northward from about $2 \mathrm{~km}$ below OBSC17 to about $4 \mathrm{~km}$ below OBSC22 (Fig. 11c). Similarly, crust of the West Philippine Basin along the C-Line thickened northward from $6 \mathrm{~km}$ below OBSC17 to $8.5 \mathrm{~km}$ below OBSC21 - OBSC26 (Fig. 11c). Structural thickening northward has been associated with northward shearing (or transpression shown in Figs. 1 and 11c) that also generated rugged basements (Chen et al. 2008) and several velocity anomaly zones east of the ridge (Wang et al. 2008). Velocity anomaly zones in the upper crust below OBSA01 and OBSA02 along A-Line, with large lateral velocity variations of $4.8-5.6 \mathrm{~km} \mathrm{~s}^{-1}$ and low velocity of $4-5 \mathrm{~km} \mathrm{~s}^{-1}$ (red dashed lines in Fig. 11a), were found. High Poisson's ratio anomalies (about 0.295), observed based on comparison with the average Poisson's ratio $(0.285)$ in the upper crust, east of the Gagua Ridge (black dashed lines in Fig. 12a) might have been due to fractures. A velocity anomaly zone below OBSC 24 was identified from the low velocities (4.5 - $\left.6.2 \mathrm{~km} \mathrm{~s}^{-1}\right)$ of the upper crust (Fig. 11c). Beneath this facture zone, possible igneous rocks might be interpreted from high velocities $\left(7.5-7.9 \mathrm{~km} \mathrm{~s}^{-1}\right)$ in the lower crust below OBSC23 and OBSC24 (Fig. 11c). However, this velocity anomaly zone and the possible igneous rock below OBSC 23 and OBSC 24 are accompanied by a Poisson's ratio of about 0.295 in the upper crust (a black dashed line in Fig. 12c) and a Poisson's ratio of about 0.275 in the upper crust (a blue dashed frame in Fig. 12c), respectively.

The velocity anomaly zones east of the ridge, illustrated by low velocity $\left(4.5-6.2 \mathrm{~km} \mathrm{~s}^{-1}\right.$ in Fig. 11c) and relatively high Poisson's ratio (0.295 - 0.32 in Fig. 12c) in the upper crust, dip northward through the thin crust below OBSC18 and OBSC19. Moreover, velocity anomaly zones below OBSC20 and OBSC21, characterized by a relatively high Poisson's ratio (0.295 - 0.315) in the upper crust (black dashed lines in Fig. 12c), might exist. These velocity anomaly zones are similar to those along the A-Line and B-Line (Figs. 12a and $b$ ) and could have originated from transpression. Therefore, these velocity anomaly zones in the upper crust at both sides of the Gagua Ridge might result from deformed, fractured or faulted zones. However, we preferred the interpretation of velocity anomalies as fracture zones due to transpression (Karig and Wageman 1975; Karp et al. 1997; Deschamps et al. 1998; Deschamps and Lallemand 2002).

Based on these models, the possible igneous rocks in the lower crust occurred at both sides of the Gagua Ridge (Figs. 11a and c), where it was suggested that these possible igneous rocks might have formed when the Gagua Ridge was rising. The sedimentary and crustal thickness east of the Gagua Ridge varied complexly based on the pseudo-3D model (Fig. 13). From the pseudo-3D map east of the southern Gagua Ridge, the thickness of the oceanic crust is $8 \mathrm{~km}$ between $20^{\circ} 40^{\prime}-21^{\circ} 40^{\prime} \mathrm{N}$ and $6-7 \mathrm{~km}$ south of $20^{\circ} 40^{\prime} \mathrm{N}$. We suggest that the crust east of the ridge thickened abruptly northward at about $20^{\circ} 40^{\prime} \mathrm{N}$ (Fig. 13b) and has apparently been affected by the northwestward convergence of the Philippine Sea Plate. Based on the OBS modeling west of the Gagua Ridge, the thickness of the oceanic crust is $9 \mathrm{~km}$ north of $21^{\circ} 20^{\prime} \mathrm{N}$, southward increasing from $9 \mathrm{~km}$ at $21^{\circ} 20^{\prime} \mathrm{N}$ to $12 \mathrm{~km}$ at $20^{\circ} 50^{\prime} \mathrm{N}$, and southward decreasing from $12 \mathrm{~km}$ at $20^{\circ} 50^{\prime} \mathrm{N}$ to $9 \mathrm{~km}$ at $20^{\circ} 36^{\prime} \mathrm{N}$ (Fig. 13b). The observations east and west of the Gagua Ridge as well as across the ridge might result from a transpression that might also have generated left-lateral strike-slip faults at both sides of the Gagua Ridge. Therefore, the Gagua Ridge was generated by compression, shearing and uplifting (or transpression) due to the northwestward convergence of the Philippine Sea Plate and also affected by eastward convergence of the Eurasia Plate.

Secondary ridges at both sides of the Gagua Ridge are located at OBSA01 - OBSA02 and OBSA04 - OBSA05 along the A-Line (Fig. 11a). The widths of the Eastern (about $35 \mathrm{~km}$ wide) and Western (about $15 \mathrm{~km}$ wide) Trough between $21^{\circ} 20^{\prime}-21^{\circ} 40^{\prime} \mathrm{N}$ (Fig. 13a) thus can be estimated from the Gagua Ridge toes (near OBSA03 and OBSA04 in Fig. 11a) to the secondary ridges. Based on the pseudo-3D map constructed from four OBS profiles of the 
southern Gagua Ridge (Fig. 13a), the sedimentary thickness and width in the Eastern $(2.0-3.0 \mathrm{~km}$ thick and $5-15 \mathrm{~km}$ wide) and Western (1.5 - $2.0 \mathrm{~km}$ thick and $15-35 \mathrm{~km}$ wide) Troughs of the Gagua Ridge are southward decreasing. On one hand, the Eastern Trough of the Gagua Rridge is thicker and wider than the Western Trough. On the other hand, possible fracture zones below the Western Trough are denser than those below the Eastern Trough. Thinner sediments, narrower trough and denser velocity anomaly zones in the Western Trough may imply that the area located west of the Gagua Ridge, near the Philippine Sea Plate boundary has been subject to more compression than that located east of the Gagua Ridge.

The crust of the Gagua Ridge thickened northward between the A-Line and MGL0908-09, and present regional variation in the crustal thickness on both sides of the Gagua Ridge (Fig. 13b). These variations resulted from compression across the ridge and also the shearing parallel to the ridge. The possible fracture zones near the Gagua Ridge linked (Fig. 13) from 4 OBS models might result from transpression. Moreover, the width of the Gagua Ridge, with crustal thickness $>10 \mathrm{~km}$, between $21^{\circ} 20^{\prime}-21^{\circ} 40^{\prime} \mathrm{N}$ is decreasing southward (Fig. 13b).

Thickness $(6-8 \mathrm{~km})$ and velocity $\left(5.0-7.5 \mathrm{~km} \mathrm{~s}^{-1}\right)$ of the oceanic crust at the Mid-Ocean Ridge in the North Atlantic (Detrick et al. 1993) were similar to those in the West Philippine Basin east of the Gagua Ridge (Figs. 11c and 13b). However, the oceanic crust $(9-13 \mathrm{~km})$ with small P-wave velocity $\left(5.0-7.0 \mathrm{~km} \mathrm{~s}^{-1}\right)$ in the Huatung Basin west of the Gagua Ridge (Figs. 11b and 13b) thicker than that east of the Gagua Ridge might have been due to compression from NW convergence of the Philippine Sea Plate. The thickness $(5.5-6.0 \mathrm{~km})$ and velocity $\left(5.0-7.8 \mathrm{~km} \mathrm{~s}^{-1}\right)$ of the oceanic crust formed at most of the transform faults along the East
Pacific Rise (Begnaud et al. 1997) were different from the oceanic crust subjected to transpression east and west of the Gagua Ridge. The crustal structures at the Puysegur Ridge and the surrounding basins off South New Zealand (Collot et al. 1995), including thrust faults, fracture zones and igneous rocks, were otherwise similar to the crustal structures of the Gagua Ridge and surrounding the Huatung and Philippine basins. The Puysegur Ridge and the Gagua Ridge were formed by transforming to compression and an incipient subduction that might have occurred during ridge formation (Lebrun et al. 2003).

\section{CONCLUSIONS}

Possible fracture zones, indicated by large lateral variations in P-wave velocity $\left(5.0-6.4 \mathrm{~km} \mathrm{~s}^{-1}\right)$, low P-wave velocity $\left(4.0-5.0 \mathrm{~km} \mathrm{~s}^{-1}\right)$ and relatively high Poisson's ratio (0.02 - 0.04 laterally higher) in the crust from the four-component OBS data modeling, were found across the southern Gagua Ridge and east of the ridge. Similarly, possible fracture zones west of the ridge were observed from large lateral variations in P-wave velocity $\left(4.5-6.2 \mathrm{~km} \mathrm{~s}^{-1}\right)$, low P-wave velocity $\left(4.5-5.0 \mathrm{~km} \mathrm{~s}^{-1}\right)$, and relatively high Poisson's ratio (0.02 - 0.04 laterally higher) in the crustal model. Fractures parallel to the ridge presented in this paper characterized E - W compression during and after the Gagua Ridge formation.

Transpression and NW convergence of the Philippine Sea Plate were associated with the Gagua Ridge formation and also resulted in the abrupt crustal thickening northward, below OBSC19 - OBSC21 (Fig. 11c) along the C-Line at about $20^{\circ} 40^{\prime} \mathrm{N}$ (Fig. 13b), and along the Eastern Trough of the Gagua Ridge imaged from OBS data (Fig. 11c). Crustal thickening southward, north of the possible fracture zone
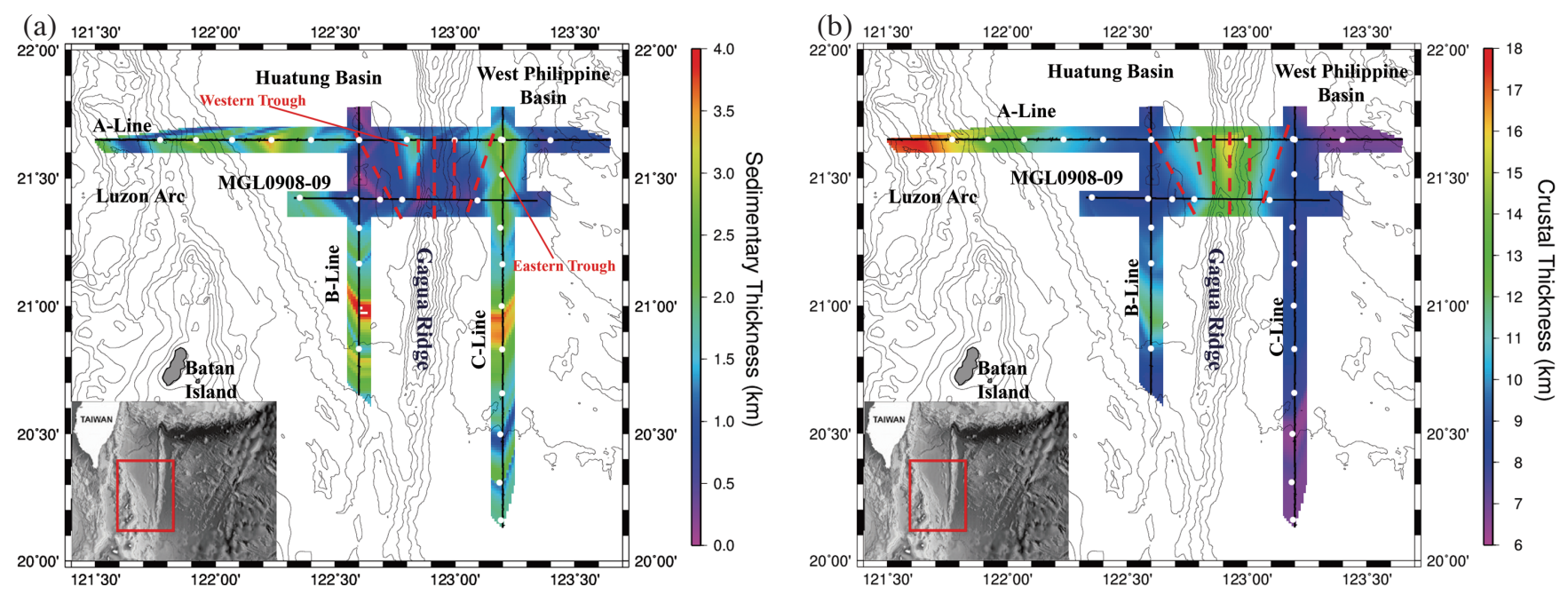

Fig. 13. (a) Thickness of the sediment (1.57 - $\left.4.5 \mathrm{~km} \mathrm{~s}^{-1}\right)$, and (b) the crustal thickness along A-Line, B-Line, C-Line, and MGL0908-09 (Mirza 2012) across the Gagua Ridge in the west Philippine Sea Plate. Contour is the bathymetry in the western Philippine Sea. White circles denoted OBSs. Red dashed lines indicated the velocity anomaly zones from P-wave velocity models in Fig. 11. 
below OBSB16 (Fig. 11b) and along B-Line north of $21^{\circ} \mathrm{N}$ (Fig. 13b), in the Huatung Basin may support the transpression at both sides of the ridge. Based on a P-wave velocity model across the Gagua Ridge (Fig. 11a), an asymmetrical structure, with crustal thickness of about 10 and $7 \mathrm{~km}$ thick west and east of the ridge, was constructed. Differences in the crustal thickness resulted from the Gagua Ridge being a transpressive plate boundary during oblique compression of the Philippine Sea Plate. We suggest that the Huatung Basin is younger than the West Philippine Basin (Deschamps et al. 1998) although the Huatung Basin did not over-thrust the West Philippine Basin as the west-dipping thrust below the Eastern Trough of the Gagua Ridge is not apparent in the OBS model. Therefore, the Gagua Ridge was formed by transpression and an incipient subduction may have occurred during the ridge formation, such as in the Puysegur Ridge formation in the South Ocean (Collot et al. 1995; Lebrun et al. 2003).

Acknowledgements Seismic surveys for this work conducted by NTOU and NTU teams in 2006 are acknowledged. We appreciate the continuous support from the Ministry of Science and Technology, Taiwan. Study of OBS data near the southern Gagua Ridge in the western Philippine Sea can be consulted upon the request.

\section{REFERENCES}

Auffret, Y., P. Pelleau, F. Klingelhoefer, L. Geli, J. Crozon, J. Y. Lin, and J. C. Sibuet, 2004: MicrOBS: A new generation of ocean bottom seismometer. First Break, 22, 41-47, doi: 10.3997/1365-2397.2004012. [Link]

Begnaud, M. L., J. S. McClain, G. A. Barth, J. A. Orcutt, and A. J. Harding, 1997: Velocity structure from forward modeling of the eastern ridge-transform intersection area of the Clipperton Fracture Zone, East Pacific Rise. J. Geophys. Res., 102, 7803-7820, doi: 10.1029/96JB03393. [Link]

Bowin, C., R. S. Lu, C. S. Lee, and H. Schouten, 1978: Plate convergence and accretion in the Taiwan-Luzon region. Bull. Am. Assoc. Petr. Geol., 62, 1645-1672.

Chen, T. R., J. M. Deng, T. K. Wang, C. S. Lee, and C. S. Liu, 2008: OBS imaging of oceanic crust paralleled to the Gagua Ridge in the West Philippine Basin. Asia Oceania Geosciences Society $5^{\text {th }}$ Annual Meeting, SE73-008.

Collot, J. Y., G. Lamarche, R. A. Wood, J. Delteil, M. Sosson, J. F. Lebrun, and M. F. Coffin, 1995: Morphostructure of an incipient subduction zone along a transform plate boundary: Puysegur Ridge and Trench. Geology, 23, 519-522, doi: 10.1130/0091-7613(1995) 023<0519:MOAISZ>2.3.CO;2. [Link]

Deng, J. M., T. R. Chen, T. K. Wang, C. S. Lee, and C. S. Liu, 2008: Velocity-interface structure across the Ga- gua Ridge in the West Philippine Basin from MicroOBS/MCS data. Asia Oceania Geosciences Society $5^{\text {th }}$ Annual Meeting, SE73-007.

Deschamps, A. and S. Lallemand, 2002: The West Philippine Basin: An Eocene to early Oligocene back arc basin opened between two opposed subduction zones. J. Geophys. Res., 107, doi: 10.1029/2001JB001706. [Link]

Deschamps, A. E., S. E. Lallemand, and J. Y. Collot, 1998: A detailed study of the Gagua Ridge: A fracture zone uplifted during a plate reorganisation in the Mid-Eocene. Mar. Geophys. Res., 20, 403-423, doi: 10.1023/ A:1004650323183. [Link]

Detrick, R. S., R. S. White, and G. M. Purdy, 1993: Crustal structure of north Atlantic Fracture Zones. Rev. Geophys., 31, 439-458, doi: 10.1029/93RG01952. [Link]

Dominguez, S., S. Lallemand, J. Malavieille, and P. Schnürle, 1998: Oblique subduction of the Gagua Ridge beneath the Ryukyu accretionary wedge system: Insights from marine observations and sandbox experiments. Mar. Geophys. Res., 20, 383-402, doi: 10.1023/ A: 1004614506345 . [Link]

Evans, C. A. and S. Lewis, 1984: The tectonic significance of the Gagua Ridge, Luzon-Taiwan Region. Eos, Trans., $A G U$, 65, 1132, doi: 10.1029/EO065i045p00831. [Link]

Hall, R., J. R. Ali, C. D. Anderson, and S. J. Baker, 1995: Origin and motion history of the Philippine Sea Plate. Tectonophysics, 251, 229-250, doi: 10.1016/00401951(95)00038-0. [Link]

Hilde, T. W. C. and C. S. Lee, 1984: Origin and evolution of the West Philippine Basin: A new interpretation. Tectonophysics, 102, 85-104, doi: 10.1016/0040-1951(84)90009-X. [Link]

Karig, D. E. and J. M. Wageman, 1975: Structure and sediment distribution in the northwest corner of the West Philippine Basin. In: Karig, D. E., J. C. Ingle Jr., A. H. Bouma, C. H. Ellis, N. Haile, I. Koizumi, H. Y. Ling, I. MacGregor, J. C. Moore, H. Ujiie, T. Watanabe, S. M. White, M. Yasui, and S. M. White (Eds.), Initial Reports of the Deep Sea Drilling Project, Vol. XXXI, U.S. Government Printing Office, Washington, D.C., 615-620, doi: 10.2973/dsdp.proc.31.129.1975. [Link]

Karp, B. Y., R. Kulinich, C. T. Shyu, and C. Wang, 1997: Some features of the arc-continent collision zone in the Ryukyu subduction system, Taiwan Junction area. Isl. Arc, 6, 303-315, doi: 10.1111/j.1440-1738.1997. tb00180.x. [Link]

Kruse, S. E., M. C. McCarthy, M. R. Brudzinski, and M. E. Ranieri, 1996: Evolution and strength of Pacific fracture zones. J. Geophys. Res., 101, 13731-13740, doi: 10.1029/96JB00645. [Link]

Lebrun, J. F., G. Lamarche, and J. Y. Collot, 2003: Subduction initiation at a strike-slip plate boundary: 
The Cenozoic Pacific-Australian plate boundary, south of New Zealand. J. Geophys. Res., 108, doi: 10.1029/2002JB002041. [Link]

McCarthy, M. C., S. E. Kruse, M. R. Brudzinski, and M. E. Ranieri, 1996: Changes in plate motions and the shape of Pacific fracture zones. J. Geophys. Res, 101, 1371513730, doi: 10.1029/96JB00646. [Link]

McIntosh, K., Y. Nakamura, T. K. Wang, R. C. Shih, A. Chen, and C. S. Liu, 2005: Crustal-scale seismic profiles across Taiwan and the western Philippine Sea. Tectonophysics, 401, 23-54, doi: 10.1016/j. tecto.2005.02.015. [Link]

Mirza, A., 2012: A long-offset reflection and refraction study across the Gagua Ridge in the West Philippine Basin. Master Thesis, National Taiwan Ocean University, Taiwan, 69 pp.

Mrozowski, C. L., S. D. Lewis, and D. E. Hayes, 1982: Complexities in the tectonic evolution of the West Philippine Basin. Tectonophysics, 82, 1-24, doi: 10.1016/0040-1951(82)90085-3. [Link]

Murauchi, S., N. Den, S. Asano, H. Hotta, T. Yoshii, T. Asanuma, K. Hagiwara, K. Ichikawa, T. Sato, W. J. Ludwig, J. I. Ewing, N. T. Edgar, and R. E. Houtz, 1968: Crustal structure of the Philippine Sea.J. Geophys. Res., 73, 3143-3171, doi: 10.1029/JB073i010p03143. [Link]

Operto, S., 1996: RSTTI package: Ray base seismic travel time inversion. University of Texas Institute for Geophysics: Technical Report, Vol. 148, 1-40.

Schnürle, P., C. S. Liu, S. E. Lallemand, and D. L. Reed, 1998a: Structural insight into the south Ryukyu margin: Effects of the subducting Gagua Ridge. Tectonophysics, 288, 237-250, doi: 10.1016/S0040-1951(97)00298-9. [Link]

Schnürle, P., C. S. Liu, S. E. Lallemand, and D. Reed, 1998b: Structural controls of the Taitung Canyon in the Huatung Basin east of Taiwan. Terr. Atmos. Ocean. Sci., 9, 453-472.

Sibuet, J. C. and S. K. Hsu, 2004: How was Taiwan created? Tectonophysics, 379, 159-181, doi: 10.1016/j. tecto.2003.10.022. [Link]

Sibuet, J. C., B. Deffontaines, S. K. Hsu, N. Thareau, J. P. Le Formal, C. S. Liu, J. Angelier, J. Y. Collot, S. Dominguez, M. Fournier, S. Lallemand, C. Y. Lu, J. Malavieille, P. Schnürle, and C. Wang, 1998: Okinawa trough backarc basin: Early tectonic and magmatic evolution. J. Geophys. Res., 103, 30245-30267, doi:
10.1029/98JB01823. [Link]

Sibuet, J. C., S. K. Hsu, X. Le Pichon, J. P. Le Formal, D. Reed, G. Moore, and C. S. Liu, 2002: East Asia plate tectonics since $15 \mathrm{Ma}$ : Constraints from the Taiwan region. Tectonophysics, 344, 103-134, doi: 10.1016/ S0040-1951(01)00202-5. [Link]

Sibuet, J. C., S. K. Hsu, and A. Normand, 2004: Tectonic significance of the Taitung Canyon, Huatung Basin, east of Taiwan. Mar. Geophys. Res., 25, 95-107, doi: 10.1007/s1 1001-005-0736-2. [Link]

Wang, T. K. and C. H. Pan, 2001: Crustal Poisson's ration off eastern Taiwan from OBS data modeling. Terr. Atmos. Ocean. Sci., 12, 249-268.

Wang, T. K., K. McIntosh, Y. Nakamura, C. S. Liu, and H. W. Chen, 2001: Velocity-interface structure of the southwestern Ryukyu subduction zone from EW95091 OBS/MCS data. Mar. Geophys. Res., 22, 265-287, doi: 10.1023/A:1014671413264. [Link]

Wang, T. K., M. K. Chen, C. S. Lee, and K. Xia, 2006: Seismic imaging of the transitional crust across the northeastern margin of the South China Sea. Tectonophysics, 412, 237-254, doi: 10.1016/j.tecto.2005.10.039. [Link]

Wang, T. K., J. M. Deng, T. R. Chen, and C. S. Lee, 2007: OBS imaging of crustal structures across Gagua Ridge in the West-Philippine Basin. Asia Oceania Geosciences Society $4^{\text {th }}$ Annual Meeting, SE04-A0026.

Wang, T. K., C. S. Lee, B. J. Yang, J. M. Deng, and T. R. Chen, 2008: Deep seismic imaging of crustal structures in the northern South China Sea and the western Philippine Sea between TAICRUST and TAIGER. Eos, Trans., AGU, 89, T33E-01.

Yang, Y. S. and T. K. Wang, 1998: Crustal velocity variation of the western Philippine Sea Plate from TAICRUST OBS/MCS Line 23. Terr. Atmos. Ocean. Sci., 9, 379-393.

Zelt, C. A. and R. B. Smith, 1992: Seismic traveltime inversion for 2-D crustal velocity structure. Geophys. J. Int., 108, 16-34, doi: 10.1111/j.1365-246X.1992.tb00836.x. [Link]

Zhao, M., X. Qiu, S. Xia, H. Xu, P. Wang, T. K. Wang, C. S. Lee, and K. Xia, 2010: Seismic structure in the northeastern South China Sea: S-wave velocity and $V \mathrm{p} / V \mathrm{~s}$ ratios derived from three-component OBS data. Tectonophysics, 480, 183-197, doi: 10.1016/j. tecto.2009.10.004. [Link] 